\title{
Human high-altitude adaptation: forward genetics meets the HIF pathway
}

\author{
Abigail W. Bigham ${ }^{1}$ and Frank S. Lee ${ }^{2}$ \\ ${ }^{1}$ Department of Anthropology, University of Michigan, Ann Arbor, Michigan 48109, USA; ${ }^{2}$ Department of Pathology and \\ Laboratory Medicine, Perelman School of Medicine, University of Pennsylvania, Philadelphia, Pennsylvania 19104, USA
}

\begin{abstract}
Humans have adapted to the chronic hypoxia of high altitude in several locations, and recent genome-wide studies have indicated a genetic basis. In some populations, genetic signatures have been identified in the hypoxiainducible factor (HIF) pathway, which orchestrates the transcriptional response to hypoxia. In Tibetans, they have been found in the HIF2A (EPAS1) gene, which encodes for HIF- $2 \alpha$, and the prolyl hydroxylase domain protein 2 (PHD2, also known as EGLN1) gene, which encodes for one of its key regulators, PHD2. High-altitude adaptation may be due to multiple genes that act in concert with one another. Unraveling their mechanism of action can offer new therapeutic approaches toward treating common human diseases characterized by chronic hypoxia.
\end{abstract}

Hypoxia is a central feature of many widespread human diseases, including ischemic heart disease, stroke, anemia, chronic obstructive pulmonary disease, and pulmonary hypertension, among others. In fact, following various pathologic states, it can be seen in essentially any tissue of the body. If one were interested in experimentally devising a strategy for allowing an organism to survive under chronic hypoxia, one would perform the obvious forward genetic screen; namely, subject the organism to chronic hypoxia and then, after many generations, identify the phenotypic features and, ultimately, the underlying genetic changes. Such an approach, given its unbiased nature, could offer new insights and potentially novel therapeutic targets for promoting optimal organism and tissue responses to chronic hypoxia.

In this regard, the human species has undergone a dramatic experiment of nature. At varying times in human demographic history, humans colonized multiple highaltitude locales, including the Tibetan Plateau, the Andean Altiplano, and the Semien Plateau of Ethiopia (Fig. 1; Beall 2013). Today, $>140$ million humans live at high altitude, defined as $>2500 \mathrm{~m}$, as this is the elevation at which most people display a fall in oxygen saturation of hemoglobin (Niermeyer et al. 2001). Both the barometric pressure and the absolute concentration of oxygen decline as a function

[Keywords: EGLN1; high-altitude adaptation; HIF; hypoxia; PHD2; Tibetan adaptation]

Corresponding author: franklee@mail.med.upenn.edu

Article is online at http://www.genesdev.org/cgi/doi/10.1101/gad.250167.114. of elevation. For example, at $4000 \mathrm{~m}$, an altitude typical of the Tibetan Plateau, the oxygen concentration is only $60 \%$ of that available at sea level. For well over a century, the unique suite of physiological adaptations to chronic hypoxia observed among long-term resident populations has been well documented (for review, see Hornbein and Schoene 2001). Studies conducted over the past decade as well as more recent genomic studies support a genetic basis for these adaptations (Simonson et al. 2012; Scheinfeldt and Tishkoff 2013). Interestingly, the patterns of genetic changes differ among the three populations. Intriguingly, genetic signatures in genes of the hypoxia-inducible factor (HIF) pathway, the central pathway that transduces changes in oxygen tension to changes in gene expression, have been identified (Kaelin and Ratcliffe 2008; Lendahl et al. 2009; Majmundar et al. 2010; Semenza 2012). This suggests that in indigenous high-altitude populations, selection for adaptation to chronic hypoxia (as opposed to cold, increased UV irradiation, or some other environmental stress experienced at high altitude) is a key component of their recent human evolution.

This review discusses findings on human adaptation to high altitude, with a particular focus on Tibetans, for whom the strongest case has been made for genetic changes in the HIF pathway being linked to adaptation. In nonhuman species, studies have examined how Drosophila has adapted to experimental hypoxia (Zhou et al. 2008, 2011). Additional studies have focused on understanding physiologic adaptations to hypoxia in a variety of organisms, ranging from Andean hummingbirds to deer mice (Natarajan et al. 2013; Projecto-Garcia et al. 2013). Other studies, including ones on snow leopards, yaks, Tibetan wild boars, Tibetan macaques, naked mole rats, and Tibetan antelopes, have undertaken genomic examination of these species in order to gain insight into their adaptation (Kim et al. 2011; Qiu et al. 2012; Cho et al. 2013; Ge et al. 2013; Li et al. 2013; Fan et al. 2014). Much of this research has been discussed in a number of excellent

(c) 2014 Bigham and Lee This article is distributed exclusively by Cold Spring Harbor Laboratory Press for the first six months after the full-issue publication date (see http://genesdev.cshlp.org/site/misc/terms.xhtml). After six months, it is available under a Creative Commons License (Attribution-NonCommercial 4.0 International), as described at http:// creativecommons.org/licenses/by-nc/4.0/. 


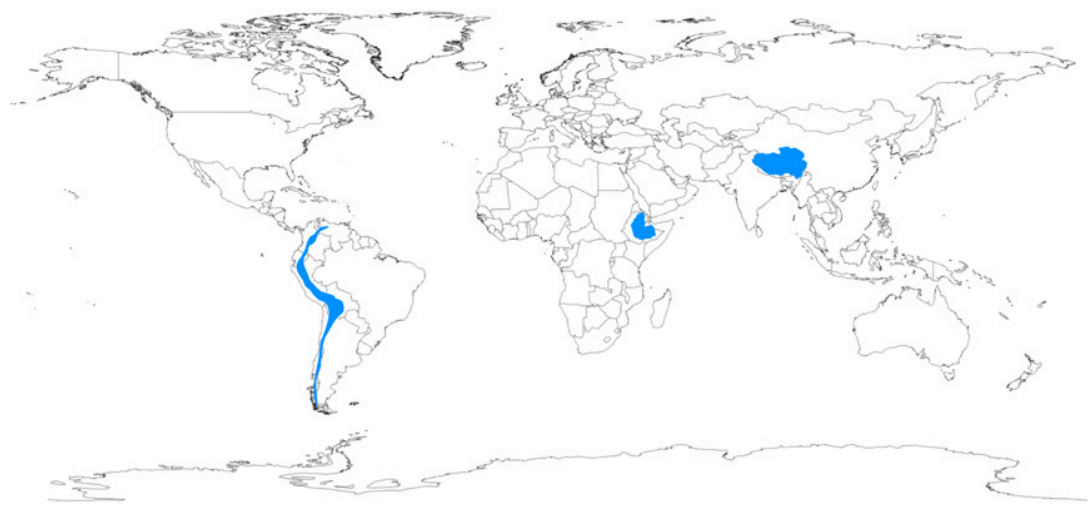

Figure 1. The geography of human adaptation to high altitude. Geographic locations where humans have adapted to life at high altitude are in blue and include (from left to right) the Andean Altiplano, the Semien Plateau, and the Tibetan Plateau. Adapted from Bigham (2008).

recent reviews (Storz et al. 2010, 2013; Zhou and Haddad 2013) and is not discussed further here.

\section{Human populations adapted to high altitude and physiologic responses}

The set of human physiological responses to hypoxia has been well documented for over a century. Beginning with the work of Francois-Gilbert Viault in the 1890s, early studies focused on the Andean pattern of physiological adaptation to high altitude (Cueto 1986). In the 1970s, research began to focus on understanding the physiological adaptations present in populations of the Tibetan Plateau. More recently, attention has turned to the Ethiopian pattern (Beall et al. 2002). Overall, this research has led to a literature documenting the suite of human physiological responses to high-altitude habitation in long-term residents of high altitude, recent low-altitude migrants to high altitude, and high-altitude sojourners (Hornbein and Schoene 2001). Each of these groups has helped us understand the extent to which the observed physiological responses to high altitude are the result of acclimatization, developmental adaptation in which trait characteristics are acquired and become fixed during the period of growth and development, or genetic adaptation. With the hypoxic challenge of increasing altitude, ambient oxygen pressure decreases, resulting in a drop in the arterial partial pressure of oxygen $\left(\mathrm{PO}_{2}\right)$ followed by a drop in arterial oxygen saturation $\left(\mathrm{SaO}_{2}\right)$. To overcome this decline in arterial oxygen content and maintain $\mathrm{O}_{2}$ homeostasis, the body responds in various ways, including increasing ventilation over the short term and increasing red blood cell production over the long term. Long-term high-altitude populations display unique circulatory, respiratory, and hematological adaptations to life at high altitude, highlighting the range of phenotypic diversity in altitude response phenotypes (Table 1). Below, we review the major physiologic adaptations to high-altitude hypoxia among these groups.

Hematocrit (the percent of whole blood composed of red blood cells) and hemoglobin (the oxygen-carrying metalloprotein in erythrocytes) concentration increases with rising altitude among high-altitude sojourners. This proliferation of red blood cells with increasing altitude allows for a greater oxygen-carrying capacity to overcome the low ambient oxygen tension experienced at high elevations. Like high-altitude sojourners, Andean highlanders exhibit elevated hemoglobin concentration in an altitude-dependent manner (Beall et al. 1990, 1998). In contrast, the Tibetan hemoglobin phenotype differs from the "classic" Andean model of erythrocytosis, the latter of which is also seen in individuals of low-altitude ancestry living at high altitude. Tibetan hemoglobin concentration is relatively low, thus characterized as a blunted (low) erythropoietic response to hypoxia challenge (Adams and Strang 1975; Beall and Reichsman 1984; Beall and Goldstein 1987). However, it is important to note that above $4000 \mathrm{~m}$, Tibetan hemoglobin concentration increases (Beall and Goldstein 1987). Tibetans, on average, have $3.5 \mathrm{~g} / \mathrm{dL}$ less hemoglobin than Andeans (Beall et al. 1998). Furthermore, concentrations of erythropoietin (EPO, a glycoprotein that controls erythropoiesis) are also slightly lower among Tibetans compared with Andeans measured at the same altitude (Winslow et al. 1989). Low hemoglobin concentration is a feature that may be adaptive because high concentrations can be associated with the hemodynamic disadvantages of hyperviscosity, its associated cardiac effects, and chronic mountain sickness (CMS). Ethiopian highlanders present yet a third hemoglobin phenotype in which their hemoglobin concentration is maintained within the ranges of sea-level populations (Beall et al. 2002).

Arterial oxygen content is a combination of the amount of oxygen bound to hemoglobin, determined by $\mathrm{SaO}_{2}$ and hemoglobin concentration, plus the amount of oxygen dissolved in arterial blood. When measured at high altitude, individuals of low-altitude ancestry who are born and raised at high altitude do not exhibit differences in their $\mathrm{SaO}_{2}$ levels compared with individuals of low-altitude ancestry who are born and raised at low altitude (Dempsey et al. 1971; Frisancho et al. 1995). For example, European sojourners to high altitude exhibit similar $\mathrm{SaO}_{2}$ values compared with Europeans born and raised at high altitude (Brutsaert et al. 2000), thus suggesting that there are no developmental effects of chronic hypoxia exposure on $\mathrm{SaO}_{2}$. Among long-term residents of high altitude, Andean highlanders display arterial oxygen levels that are $\sim 16 \%$ higher than sea-level inhabitants residing at high altitude (Beall 2006). This is due in part to their increased $\mathrm{SaO}_{2}$ levels, where Andeans maintain higher levels of $\mathrm{SaO}_{2}$ at rest and during exercise compared with sea-level inhabitants measured at the same altitude (Brutsaert et al. 2000). 
Table 1. Physiologic adaptations to high-altitude hypoxia among high-altitude populations

\begin{tabular}{llll}
\hline Phenotype & Andean & \multicolumn{1}{c}{ Tibetan } & Ethiopian \\
\hline Resting ventilation & No increase & $50 \%$ higher & NR \\
Hypoxic ventilatory response & Blunted (low) & Similar to sea level & NR \\
Arterial oxygen saturation & Elevated & No increase & Elevated \\
Hemoglobin concentration & Elevated & Minimal increase & Minimal increase \\
Pulmonary arterial pressure & Elevated & Minimal increase & Elevated \\
Nitric oxide & Elevated & Markedly elevated & NR \\
Birth weight & Elevated & Elevated & NR \\
\hline
\end{tabular}

(NR) Not reported.

Tibetan highlanders also exhibit higher levels of $\mathrm{SaO}_{2}$ compared with low-altitude residents measured at the same altitude (Wu and Kayser 2006), but their average $\mathrm{SaO}_{2}$ levels at rest are not significantly different from Han Chinese born and raised at high-altitude and are lower than those observed among Andeans when measured using the same equipment and protocol (Beall et al. 1997b, 1999; Weitz and Garruto 2007). Notably, among Tibetan women, a major autosomal dominant allele for high $\mathrm{SaO}_{2}$ has been identified in which women carrying the high oxygen saturation allele exhibit a greater offspring survival rate than women possessing the low oxygen saturation allele (Beall et al. 1994).

When acutely exposed to high altitude, lowlanders exhibit an immediate rise in ventilation known as the hypoxic ventilatory response (HVR) (Chiodi 1957). This important response to short-term high-altitude exposure is not maintained over the long-term, and resting ventilation returns to low-altitude levels after several days (Weil et al. 1971). Among indigenous high-altitude populations, two distinct pulmonary responses to continued hypoxia exposure have been observed. Andeans exhibit no increase in resting ventilation levels over low-altitude values at rest or during exercise (Chiodi 1957; Brutsaert et al. 2000) and a blunted HVR (Chiodi 1957; Beall et al. 1997a) that is commonly lower than sea-level values. Pointing to a genetic basis for this trait, the Andean HVR has been associated with Quechua ancestry (Brutsaert et al. 2005), thus suggesting an evolutionary origin. Tibetans maintain equal or higher resting ventilation compared with other acclimatized Asian and European populations measured at the same altitude (Zhuang et al. 1993; Ge et al. 1994; Beall et al. 1997a; Moore et al. 2001b), and, notably, their resting ventilation is 1.5 times higher than that observed among the Andean Aymara (Beall et al. 1997a). Furthermore, Tibetan HVR is in line with acclimatized newcomers and low-altitude populations acutely exposed to hypoxia (Zhuang et al. 1993). This suggests that Tibetans have adapted to maintain the temporary hypoxia-induced increase in ventilation observed among low-altitude native populations.

Another noteworthy pulmonary response to acute highaltitude exposure is pulmonary vasculature vasoconstriction, a subsequent consequence of which is pulmonary hypertension. Pulmonary hypertension is characteristic of several altitude-associated disorders, including acute mountain sickness (soroche) and CMS, and is a leading pathophysiological mechanism in the development of high-altitude pulmonary edema (HAPE) (Staub 1980). Long-term highaltitude residents display differences in their pulmonary vasoconstrictor response to hypoxia. For example, Tibetans display resting and exercise pulmonary arterial pressures that are in line with sea-level averages and show minimal hypoxic pulmonary hypertension (Groves et al. 1993). Furthermore, differences exist between Han and Tibetan infants in their development of pulmonary hypertension (Niermeyer et al. 1995), with subacute infantile mountain sickness (characterized by dyspnea, cyanosis, right sidedheart failure, and pulmonary hypertension) primarily observed among Han Chinese infants residing in Tibet (Sui et al. 1988). In contrast, pulmonary hypertension does exist among Andeans in both adulthood (Penaloza et al. 1963) and childhood (Sime et al. 1963), the root cause of which can be attributed to arterial structural changes that include thickening of the pulmonary arterial walls (Arias-Stella and Saldana 1962).

Traditional attention on high-altitude-adaptive phenotypes has largely focused on pulmonary and hematological factors contributing to adaptation to chronic hypoxia. However, recent research has pointed to the role of vascular factors as central components of high-altitude-adaptive phenotypes. Nitric oxide (NO) is a powerful vasodilator expressed in multiple cell types, including vascular endothelial cells, and is responsible for regulating blood flow and vascular resistance. Additionally, NO causes other cellular responses, such as arterial smooth muscle relaxation. Erzurum et al. (2007; Beall et al. 2012) showed that Tibetan highlanders exhibit greater forearm blood flow without associated hypertension or vascular resistance as well as higher levels of circulating NO compared with sealevel inhabitants. This increase in circulation could likely counteract the low levels of arterial oxygen observed in Tibetan highlanders. Other vascular changes observed among both Andean and Tibetan women include those associated with pregnancy and fetal growth. High altitude causes intrauterine growth restriction (IUGR), which results in low birth weight, an important marker of morbidity and mortality in newborns. IUGR varies with duration of altitude exposure, with multigenerational high-altitude inhabitants experiencing less reduction in birth weight than populations who have moved to high altitude more recently (Zamudio et al. 1993; Moore et al. 2001a; Julian et al. 2007). Accordingly, infants born to Andean and Tibetan women are relatively protected from altitudeassociated reductions in birth weight when compared with infants born at high altitude to European and Han women, 
respectively, who reside at the same altitude (for review, see Moore et al. 2011). Furthermore, the percentage of Andean ancestry is significantly correlated with birth weight, suggesting a genetic influence for this phenotype (Julian et al. 2007; Bennett et al. 2008; Soria et al. 2013).

Research of this nature documents the potential for natural selection to act on phenotypic traits yet does not identify the genes undergirding the observed altitudeadaptive phenotypes. Genes directly involved in the molecular response to hypoxia via the HIF pathway are natural candidates for interrogation. The HIF pathway is a complex $\mathrm{O}_{2}$-sensing system involved in embryogenesis, development, and homeostasis that activates hundreds of downstream genes in response to cellular hypoxia and is discussed in more detail below.

\section{The HIF pathway}

HIF is the master transcriptional regulator of the hypoxic response in metazoans (Semenza 1999; Giaccia et al. 2003; Wenger et al. 2005; Lendahl et al. 2009). It is a heterodimer consisting of a common $\beta$ subunit (HIF- $\beta$, also known as ARNT) and one of three $\alpha$ subunits (HIF- $1 \alpha$, HIF- $2 \alpha$, and HIF-3 $\alpha$, the first two of which have been the most extensively studied). The $\alpha$ and $\beta$ subunits contain $\mathrm{N}$-terminal helix-loop-helix (HLH) and Per Arnt Sim (PAS) domains. The $\alpha$ subunits also contain C-terminal oxygen-dependent degradation and transcriptional activation domains. The principal means by which HIF activity is controlled in response to oxygen concentration is through site-specific prolyl hydroxylation of the $\alpha$ subunit (Fig. 2A; Ivan et al. 2001; Jaakkola et al. 2001; Yu et al. 2001). Under normoxic conditions, a family of three enzymes-prolyl hydroxylase domain protein 1 (PHD1, also known as EGLN2), PHD2 (EGLN1), and PHD3 (EGLN3)-hydroxylates HIF- $\alpha$ in its oxygen-dependent degradation domain (Bruick and McKnight 2001; Epstein et al. 2001; Ivan et al. 2002). In HIF-1 $\alpha$, the primary site of hydroxylation is on Pro564; in HIF-2 $\alpha$, it is on Pro531; and in HIF-3 $\alpha$, it is on Pro490 (Ivan et al. 2001; Jaakkola et al. 2001; Masson et al. 2001; Yu et al. 2001; Hirsila et al. 2003; Maynard et al. 2003). This hydroxylation provides a binding platform for the von Hippel-Lindau (VHL) protein, a component of an E3 ubiquitin ligase complex that then targets hydroxylated HIF- $\alpha$ for degradation by the ubiquitinproteasome pathway. Under hypoxic conditions, this inherently oxygen-dependent modification is arrested, leading to the stabilization of HIF- $\alpha$ and its dimerization with HIF- $\beta$ (the stability of which is not particularly regulated by oxygen concentration). In addition to being directly sensitive to changing oxygen concentrations, it must be recognized that the PHDs are also responsive to reactive oxygen species, iron and ascorbate concentrations, and Krebs cycle intermediates (Ratcliffe 2013). Therefore, the PHDs can respond to a variety of signals. Also, while hydroxylation is the key post-translational modification regulating HIF activity in response to changing oxygen concentration, it should be noted that other post-translational modifications, including acetylation and phosphorylation, can modulate HIF activity as well (Greer et al. 2012; Keith et al. 2012; Mennerich and Kietzmann 2014).
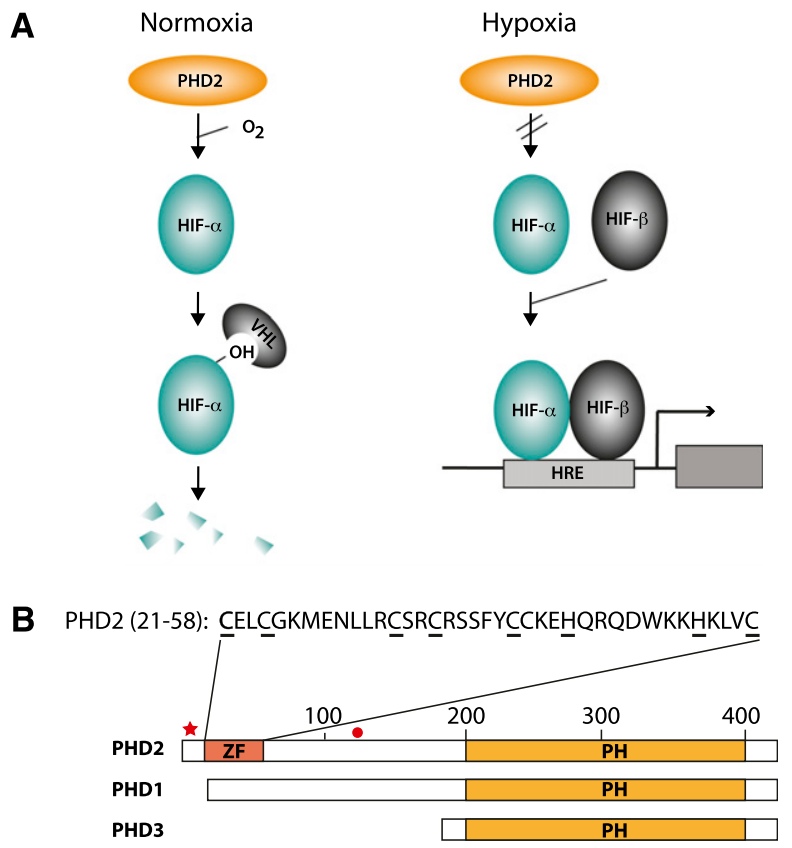

Figure 2. (A) The PHD2:HIF pathway. (Left) Under normoxic conditions, PHD2 constitutively prolyl hydroxylates HIF- $\alpha$, targeting it for degradation in a VHL-dependent manner. (Right) Under hypoxic conditions, the hydroxylation is arrested, allowing HIF- $\alpha$ stabilization, dimerization with HIF- $\beta$, and binding to hypoxia response elements (HREs) that control target genes. $(B)$ The three PHDs. The prolyl hydroxylase $(\mathrm{PH})$ domain resides at the C-terminal end of each paralog. PHD2 is distinctive in harboring a MYND zinc finger ( $\mathrm{ZF}$ ) at its $\mathrm{N}$ terminus. The amino acid sequence of this zinc finger (residues 21-58) is shown. Underlines denote predicted zinc chelating residues. The positions of PHD2 Asp4 and Cys127 are indicated by a red star and a black circle, respectively.

The PHDs are members of a family of 2-oxoglutaratedependent dioxygenases (McDonough et al. 2010). A distinct member of this family, factor inhibitor HIF (FIH), provides an additional layer of regulation of HIF- $\alpha$. Specifically, FIH hydroxylates an asparagine residue in the transcriptional activation domain of HIF (Asn803 of HIF$1 \alpha$ and Asn851 of HIF-2 $\alpha$ ) (Hewitson et al. 2002; Lando et al. 2002a,b). Under normoxia, this modification blocks interaction with the transcriptional coactivator CBP/p300, while, under hypoxia, attenuation of this modification allows functional interaction between the two and hence transcriptional activation. In general, both $\mathrm{FIH}$ and the PHDs more efficiently hydroxylate long peptide/protein substrates over short peptide substrates (Koivunen et al. 2004; Ehrismann et al. 2007). Hydroxylation can therefore influence HIF activity by two distinct mechanisms: through protein stability and transcriptional activation.

Once stabilized, HIF- $\alpha$ dimerizes with HIF- $\beta$ via their HLH and PAS domains and then activates hundreds of genes involved in systemic and cellular adaptation to hypoxia (Mole et al. 2009; Xia et al. 2009; Schodel et al. 2011). HIF- $1 \alpha$ and HIF- $\alpha$ activate overlapping as well as distinct genes and cellular responses. For example, HIF$1 \alpha$ is the principal paralog that up-regulates genes encod- 
ing glycolytic enzymes (Semenza 1999). Moreover, HIF- $1 \alpha$ inhibits oxidative phosphorylation and mitochondrial biogenesis (Kim et al. 2006a; Papandreou et al. 2006; Zhang et al. 2007). HIF-1 $\alpha$ is also essential for proper maintenance of hematopoietic stem cell quiescence (Takubo et al. 2010). HIF-2 $\alpha$, on the other hand, is the paralog critical for regulating the EPO gene in specialized interstitial cells in the adult kidney (Fig. 3; Lee and Percy 2011). The product of this gene, EPO, is the central regulator of red cell mass. Studies using genetically modified mice have provided critical evidence for this, since Hif2 $a$ loss of function (LOF) is accompanied by anemia, whereas Hif2a gain of function (GOF) produces erythrocytosis (Table 2; Scortegagna et al. 2005; Kim et al. 2006b; Gruber et al. 2007; Hickey et al. 2010; Kapitsinou et al. 2010; Tan et al. 2013). In humans, important evidence for a role of HIF- $2 \alpha$ in EPO regulation is provided by the identification of heterozygous GOF mutations in the HIF2A gene in patients with erythrocytosis (Percy et al. $2008 \mathrm{a}, \mathrm{b})$. The residues affected by these mutations cluster around the primary site of hydroxylation, Pro531, and functionally impair prolyl hydroxylation, subsequent recognition by VHL, or (most typically) both, ultimately resulting in aberrant stabilization of the HIF- $2 \alpha$ protein (Furlow et al. 2009).

As befits factors that orchestrate the hypoxic response, HIF- $1 \alpha$ and HIF- $2 \alpha$ often act in the same direction. For example, both have the capacity to activate the VEGFA gene, which encodes for a key protein that induces angiogenesis (Keith et al. 2012). In addition, both HIF-1 $\alpha$ and HIF- $2 \alpha$ have been implicated in the pathogenesis of pulmonary hypertension (Fig. 3; Shimoda and Laurie 2014). For example, mice and some patients with HIF2A GOF mutations display pulmonary hypertension (Gale et al. 2008; Tan et al. 2013). Furthermore, in genetically engineered mouse studies, haploinsufficiency of either

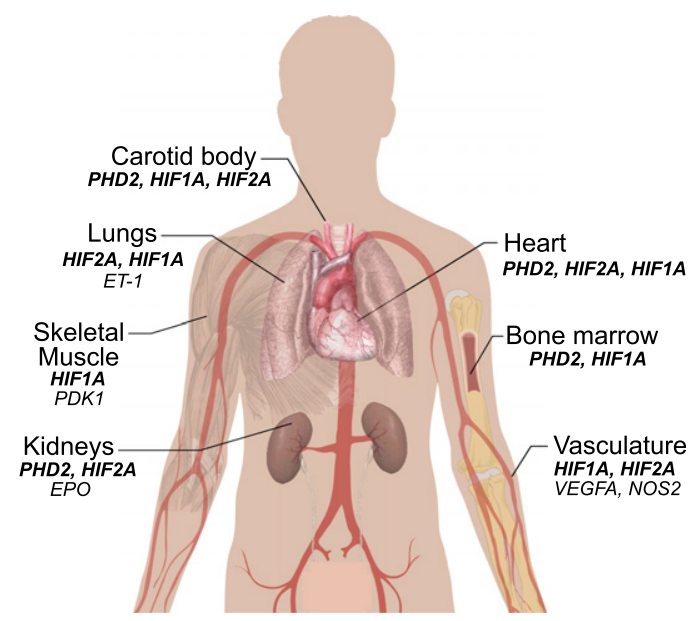

Figure 3. Potential organs involved in high-altitude adaptation, along with select HIF pathway genes (bold italics) and select HIF target genes (nonbold italics) that may be relevant. The genes shown are derived mainly from studies conducted on genetically engineered mice (see Table 2) as well as additional studies on human patients with erythrocytosis.
Hif1a or Hif2a delays or prevents hypoxia-induced (and, in the case of Hif2 $a, V h l$ mutation-associated) pulmonary hypertension (Table 2; Yu et al. 1999; Brusselmans et al. 2003; Hickey et al. 2010).

However, it is also clear that HIF- $1 \alpha$ and HIF- $2 \alpha$ can have antagonistic activities. For example, HIF- $1 \alpha$ promotes cell cycle arrest, whereas HIF- $2 \alpha$ promotes progression through the cell cycle, likely in a cell context-dependent manner (Keith et al. 2012). In murine macrophages, keratinocytes, and endothelial cells, Hif- $1 \alpha$ promotes NO production through activation of the inducible NO synthase (Nos2) gene, whereas Hif- $2 \alpha$ inhibits NO production through the induction of the arginase (Arg) gene (Takeda et al. 2010; Branco-Price et al. 2012; Cowburn et al. 2013). Finally, $\mathrm{Hifl}^{+/-}$mice display blunted respiratory responses to chronic hypoxia, while $H i f 2 a^{+-}$mice display exaggerated carotid body sensitivity to hypoxia (Fig. 3; Kline et al. 2002; Peng et al. 2011b; Yuan et al. 2013). Far less is known regarding HIF-3 $\alpha$ targets, but current data indicate that it can act as both an activator and inhibitor of gene transcription (Makino et al. 2001; Zhang et al. 2014).

As with the HIFs, the PHDs have overlapping and distinct functions. Among the three paralogs, PHD2 has emerged as perhaps the most important. Conventional knockout of $P h d 2$ in mice, for example, leads to embryonic lethality, in contrast to that of Phd1 or Phd3, each of which leads to viable, fertile mice (Takeda et al. 2006). Phd2 has a broad tissue expression, and, in many transformed cell lines, knockdown of PHD2 is sufficient to induce HIF- $\alpha$ stabilization (although typically not to the extent seen in hypoxia) (Berra et al. 2003; Appelhoff et al. 2004).

PHD2 also plays a distinctly critical role-through its regulation of HIF- $2 \alpha$-in the control of EPO gene transcription in interstitial cells of the kidney and hence red cell mass (Lee and Percy 2011). This was initially demonstrated by the identification of human erythrocytosis patients with heterozygous LOF mutations in the PHD2 gene (Percy et al. 2006, 2007; Al-Sheikh et al. 2008; Ladroue et al. 2008). These mutations, it should be noted, typically affect residues that reside in the catalytic domain of the protein (Gardie et al. 2014). Subsequent studies using global conditional knockout of the Phd2 gene demonstrated that it plays the dominant role, among the Phd paralogs, in the control of renal Epo (Minamishima et al. 2008; Takeda et al. 2008). Studies also have shown that $\mathrm{Phd} 2$ plays a role in regulating respiratory drive. Specifically, loss of Phd2 function is associated with increased respiration (Arsenault et al. 2013; Bishop et al. 2013). Importantly, this phenotype is not seen in either Phd1 $1^{-/-}$or Phd3 ${ }^{-/-}$mice (Bishop et al. 2013). PHD1 and PHD3 also have been studied, although not as extensively as PHD2. The Phd3 gene is a HIF target and is a component of a negative feedback loop that down-regulates HIF activity (Minamishima et al. 2009). In the murine liver, Phd3 also plays a vital role-via its control of Hif- $2 \alpha$-in regulating Irs 2 transcription and hence insulin signaling (Taniguchi et al. 2013).

The three PHDs share a common prolyl hydroxylase domain but are quite different at their $\mathrm{N}$ terminii (Fig. 2B; Taylor 2001). PHD2 possesses a predicted myeloid nervy 
Table 2. Select mouse lines with genetically engineered alterations in the Phd2, Hif2a, and Hif1a genes that have potential relevance to high-altitude adaptation

\begin{tabular}{|c|c|c|c|c|}
\hline Genotype & Effect & Tissues & Phenotype & Reference \\
\hline \multicolumn{5}{|l|}{ Phd2 alleles } \\
\hline$P h d 2^{+1-}$ & LOF & Global & Mild erythrocytosis & $\begin{array}{l}\text { Mazzone et al. 2009; } \\
\text { Li et al. } 2010\end{array}$ \\
\hline $\mathrm{Phd}^{+/-}$ & LOF & Global & Increased HVR; carotid body hyperplasia & Bishop et al. 2013 \\
\hline Phd2 $2^{\mathrm{P} 294 \mathrm{R} /+}$ & LOF & Global & $\begin{array}{l}\text { Increased respiration under normoxia; } \\
\text { mild erythrocytosis }\end{array}$ & Arsenault et al. 2013 \\
\hline Rosa26-creER; Phd2 $\mathrm{f}^{\mathrm{f} / \mathrm{f}}$ & LOF & Global & $\begin{array}{l}\text { Marked erythrocytosis; increased } \\
\text { vascular growth in multiple tissues }\end{array}$ & $\begin{array}{l}\text { Takeda et al. 2007, 2008; } \\
\text { Li et al. } 2010\end{array}$ \\
\hline Bactin-creER; Phd2 $2^{\mathrm{f} / \mathrm{f}}$ & LOF & Global & Marked erythrocytosis; cardiomyopathy & Minamishima et al. 2008 \\
\hline Pax3-cre; $P h d 2^{\mathrm{f} / \mathrm{f}}$ & LOF & Neural crest & Marked erythrocytosis & Arsenault et al. 2013 \\
\hline Vav1-cre; $P h d 2^{\mathrm{f} / \mathrm{f}}$ & LOF & Hematopoietic & Mild erythrocytosis & Arsenault et al. 2013 \\
\hline CD68-cre; $P h d 2^{\mathrm{f} / \mathrm{f}}$ & LOF & Selected ${ }^{\mathrm{a}}$ & Marked erythrocytosis & Franke et al. 2013 \\
\hline$\alpha M H C$-cre; $P h d 2^{\mathrm{f} / \mathrm{f}}$ & LOF & Heart & Cardiomyopathy & Moslehi et al. 2010 \\
\hline$M L C V$-cre; $P h d 2^{\mathrm{f} / \mathrm{f}}$ & LOF & Heart & Increased capillary area in hearts & Holscher et al. 2011 \\
\hline$P h d 2^{\mathrm{gt} / \mathrm{gt}}$ & LOF & Selected ${ }^{\mathrm{b}}$ & $\begin{array}{l}\text { Increased cardiac capillary size; } \\
\text { increased NO production } \\
\text { following cardiac ischemia } \\
\text { reperfusion injury }\end{array}$ & Kerkela et al. 2013 \\
\hline$A l b$-cre; $P h d 2^{\mathrm{f} / \mathrm{f}}$ & LOF & Liver & Activation of Hif- $1 \alpha$ but not Hif- $2 \alpha$ & Taniguchi et al. 2013 \\
\hline \multicolumn{5}{|l|}{ Hif2 $a$ alleles } \\
\hline Hif $2 a^{-1-}$ & LOF & Global & Anemia $^{\mathrm{c}}$ & Scortegagna et al. 2005 \\
\hline$U b c$-cre; Hif2 $a^{\mathrm{f} / \mathrm{f}}$ & LOF & Global & Anemia & Gruber et al. 2007 \\
\hline $\mathrm{Hif} 2 \mathrm{a}^{+/-}$ & LOF & Global & $\begin{array}{l}\text { Resistance to hypoxia-induced } \\
\text { pulmonary hypertension }\end{array}$ & Brusselmans et al. 2003 \\
\hline Hif $2 a^{+/-d}$ & LOF & Global & $\begin{array}{l}\text { Resistance to Chuvash } \\
\text { polycythemia-associated } \\
\text { erythrocytosis and pulmonary } \\
\text { hypertension }\end{array}$ & Hickey et al. 2010) \\
\hline Hif $2 a^{+/-}$ & LOF & Global & Exaggerated HVR & Peng et al. $2011 \mathrm{~b}$ \\
\hline Pax3-cre; Hif2a $a^{\mathrm{f} / \mathrm{f}}$ & LOF & Neural crest & Anemia & Kapitsinou et al. 2010 \\
\hline LysM-cre; Hif2a $a^{\mathrm{f} / \mathrm{f}}$ & LOF & Macrophage & $\begin{array}{l}\text { Enhanced NO production } \\
\text { from macrophages }\end{array}$ & Takeda et al. 2010 \\
\hline K14-cre; Hif2a $a^{\mathrm{f} / \mathrm{f}}$ & LOF & Keratinocyte & $\begin{array}{l}\text { Increased skin nitrate (NO } \\
\text { derivative) levels }\end{array}$ & Cowburn et al. 2013 \\
\hline Alb-cre; HIF2dPA & GOF & Liver & Erythrocytosis & Kim et al. $2006 b$ \\
\hline Hif2 $a^{\mathrm{G} 536 \mathrm{~W} /+}$ & GOF & Global & $\begin{array}{l}\text { Erythrocytosis and pulmonary } \\
\text { hypertension }\end{array}$ & Tan et al. 2013 \\
\hline$\alpha M H C$-cre; HIF2dPA & GOF & Heart & Cardiomyopathy & Moslehi et al. 2010 \\
\hline Vil-cre; Hif2a $a^{\mathrm{f} / \mathrm{f}}$ & LOF & Intestine & Impaired iron absorption & $\begin{array}{l}\text { Mastrogiannaki et al. 2009; } \\
\text { Anderson et al. } 2011\end{array}$ \\
\hline VEcad-cre; Hif2a $a^{\mathrm{f} / \mathrm{f}}$ & LOF & Endothelium & Defective revascularization & Skuli et al. 2012 \\
\hline \multicolumn{5}{|l|}{ Hif1a alleles } \\
\hline Hif1 $a^{+/-}$ & LOF & Global & $\begin{array}{l}\text { Delayed development of } \\
\text { hypoxia-induced } \\
\text { pulmonary hypertension }\end{array}$ & Yu et al. 1999 \\
\hline Hif1 $a^{+/-}$ & LOF & Global & Impaired HVR following chronic hypoxia & Kline et al. 2002 \\
\hline LysM-cre; Hif $1 a^{\mathrm{f} / \mathrm{f}}$ & LOF & Macrophage & $\begin{array}{l}\text { Impaired NO production from } \\
\text { macrophages }\end{array}$ & Takeda et al. 2010 \\
\hline Tie2-cre; Hif1 $a^{\mathrm{f} / \mathrm{f}}$ & LOF & Endothelium & $\begin{array}{l}\text { Impaired NO production from } \\
\text { endothelial cells }\end{array}$ & Branco-Price et al. 2012 \\
\hline$M C K$-cre; Hif1 $a^{\mathrm{f} / \mathrm{f}}$ & LOF & $\begin{array}{l}\text { Skeletal } \\
\text { muscle }\end{array}$ & Shift from glycolysis to oxidation & Mason et al. 2004, 2007 \\
\hline$M L C 2 v ; H i f 1 a^{\mathrm{f} / \mathrm{f} \mathrm{e}}$ & LOF & Heart & $\begin{array}{l}\text { Protection from } V h l \text { loss-induced } \\
\text { cardiac degeneration }\end{array}$ & Lei et al. 2008 \\
\hline
\end{tabular}

Selected aspects of phenotype with potential relevance to high-altitude adaptation are shown. Mice with genetically engineered changes in the Vhl gene have been reviewed elsewhere (Kapitsinou and Haase 2008). (f) Floxed; (gt) gene targeted, achieved by insertion of GeneTrap targeting vector in intron 1 of Phd2 gene; (HIF2dPA) HA-HIF-2 $\alpha$ P405A;P531A expressed from the Rosa26 locus in a cre-dependent manner. ${ }^{a}$ Cells in which deletion was observed include renal Epo-producing cells, neurons, astrocytes, and hematopoietic cells.

${ }^{b}$ Ninety-two percent and $85 \%$ reduction in heart and skeletal muscle, respectively, and variable reduction in other tissues.

${ }^{\mathrm{c}}$ Pancytopenia also present.

${ }^{\mathrm{d}}$ In a $V h \mathrm{l}^{\mathrm{R} 200 \mathrm{~W} / \mathrm{R} 200 \mathrm{~W}}$ genetic background.

${ }^{\mathrm{e}}$ In a $M L C 2 v ; V h I^{\mathrm{f} / \mathrm{f}}$ genetic background. 
deaf (MYND)-type zinc finger at its $\mathrm{N}$ terminus that is absent from the other two PHDs. This zinc finger is separated by $>100$ amino acids from the catalytic domain. Unlike certain MYND-containing proteins, such as the SMYD methyltransferases, where the MYND finger interacts with the catalytic domain of the protein (Ferguson et al. 2011), evidence has yet to be presented that the MYND zinc finger of PHD2 physically interacts with the catalytic domain. The zinc finger of PHD2 is strongly conserved across species and indeed is found in the single Phd ortholog from the simplest metazoan, Trichoplax adhaerens (Loenarz et al. 2011). Hence, PHD2 is the human PHD paralog most closely related to the ancestral Phd (Loenarz et al. 2011; Rytkonen et al. 2011). Caenorhabditis elegans also possesses a single Phd ortholog that harbors a zinc finger, and, interestingly, a mutant $C$. elegans with a Phd lacking this zinc finger displays normal Hif regulation (Shao et al. 2009). A property of this zinc finger in human PHD2 is that it binds to a Pro-Xaa-Leu-Glu (PXLE) motif (Song et al. 2013). This motif is found in select HSP90 cochaperones, such as p23 and FKBP38, as well as HSP90 itself (both HSP90 $\alpha$ and HSP90 $\beta$ paralogs) (Song et al. 2013, 2014). Therefore, the zinc finger of PHD2 is a module that binds to peptides, which is consistent with known functions of other MYND zinc fingers (Matthews et al. 2009).

Differing functions for the zinc finger of PHD2 have been proposed. First, it has been proposed that the zinc finger inhibits the catalytic activity of PHD2 (Choi et al. 2005). This would predict that loss of zinc finger function would lead to augmented PHD2 activity and hence impaired HIF activation. Second, it has been observed that the interaction of PHD2 with FKBP38 promotes PHD2 degradation (Barth et al. 2007). This would predict that loss of this interaction would also lead to augmented PHD2 activity and impaired HIF activation. These first two proposals receive support from studies in Droshophila. Drosphila harbors a single Phd isoform called fatiga that is orthologous to PHD2, and a fatiga variant isoform lacking the zinc finger displays higher activity when transgenically expressed than one that contains it (Acevedo et al. 2010). A third proposal for the function of the zinc finger of PHD2 is that it facilitates HIF hydroxylation (Song et al. 2013). HIF- $\alpha$ is known to be an HSP90 client (Minet et al. 1999; Isaacs et al. 2002; Katschinski et al. 2002); hence, the interaction of PHD2 with the PXLE motif contained within an HSP90 cochaperone (such as p23) or HSP90 itself could allow recruitment of PHD2 to the HSP90 pathway to facilitate HIF- $\alpha$ hydroxylation. In contrast to the first two models, this would predict that loss of zinc finger function would lead to diminished PHD2 activity and hence augmented HIF activation.

\section{Andean and Ethiopian adaptation to high altitude and genetic analyses}

Genomic analysis of Andean populations has revealed at least 40 HIF pathway and hypoxia-related genes as candidates for natural selection to high altitude (Table 3A; Bigham et al. 2009, 2010). One hypoxia-related gene
Table 3. HIF pathway and hypoxia-related genes with genetic signatures in Andean and Tibetan populations

\begin{tabular}{|c|c|c|c|c|}
\hline \multicolumn{5}{|c|}{ (A) Andean selection-nominated genes $(n=40)^{\mathrm{a}}$} \\
\hline$A D R A 1 B$ & $E D N R A$ & $I L 1 B$ & NOTCH1 & SATB1 \\
\hline ARNT2 & $E D N R B$ & IL6 & NRP1 & SNAI3 \\
\hline ATP1A1 & EGLN1 & KCNMA1 & NRP2 & SPRY2 \\
\hline ATP1A2 & EGLN2 & MDM2 & PIKЗCA & $T F$ \\
\hline $\mathrm{CDH} 1$ & ELF2 & $M M P 2$ & POLR2A & TGFA \\
\hline COPS5 & $I G F B P 1$ & MTOR & PRKAA1 & $T N C$ \\
\hline CXCR4 & IGFBP2 & NOS1 & PRKAA2 & TNF \\
\hline EDN1 & $I L 1 \mathrm{~A}$ & NOS2 & PSMC3 & VEGFA \\
\hline \multicolumn{5}{|c|}{ (B) Tibetan selection-nominated genes $(n=39)^{\mathrm{b}}$} \\
\hline$A D R A 1 B$ & EGLN3 & HMOX2 & 10 & POLR2A \\
\hline$A R N T$ & EP300 & IGFBP1 & $N R P 1$ & PPARA \\
\hline ANGPTL4 & EPAS1 & IGFBP2 & NRP2 & $R B X 1$ \\
\hline CASR & $E P O$ & $I L 1 A$ & PDGF2 & $T N C$ \\
\hline COPS5 & FLT1 & $I L 1 B$ & $P G F$ & $T N F$ \\
\hline EDN1 & $H B B$ & IL6 & PIKЗСB & $V E G F A$ \\
\hline$E D N R A$ & $H B G 2$ & $M D M 2$ & PIKЗCG & VEGFC \\
\hline EGLN1 & HIF1A & NOS1 & $P K L R$ & \\
\hline
\end{tabular}

${ }^{\mathrm{a}}$ Data are from Bigham et al. $(2009,2010)$.

bData are from Bigham et al. (2010), Peng et al. (2011a), Simonson et al. (2010), and Yi et al. (2010).

in particular, the $\alpha-1$ catalytic subunit of adenosine monophosphate-activated protein kinase (PRKAA1, also known as $A M P K \alpha 1$ ), may be influential in achieving genetic adaptation to high altitude by affecting physiological responses to pregnancy that are instrumental for fetal growth (Bigham et al. 2014). Furthermore, whole-genome sequencing of an Andean CMS cohort implicated sentrinspecific peptidase 1 (SENP1), an enzyme implicated in erythropoiesis, and acidic leucine-rich nuclear phosphoprotein 32 family member D (ANP32D), an oncogene, in the development of CMS (Zhou et al. 2013).

Genomic signatures of natural selection among Ethiopian highlanders implicate hypoxia-related as well as non-hypoxia-related genes in adaptation to high altitude. Candidate genes include basic HLH family member e41 (BHLHE41 also known as DEC2 or SHARP1), mitochondrial calcium uptake 1 (MICU, also known as CBARA1), vav 3 guanine nucleotide exchange factor (VAV3), arylhydrocarbon receptor nuclear translocator 2 (ARNT2), and thyroid hormone receptor $\beta(T H R B)$ as well as a generich region on chromosome 19 containing several genes that are involved in vascular physiology (CXCL17 and PAFAH1B3) or have been linked to hypoxia (LIPE) (Scheinfeldt et al. 2012; Huerta-Sanchez et al. 2013; Udpa et al. 2014). Two genes in particular, ARNT2 and THRB, show suggestive relationships with hemoglobin concentration; for example, Ethiopian Amhara with two copies of the THRB rs826216 C allele display hemoglobin levels that are higher than those in individuals with two copies of the $\mathrm{T}$ allele (Scheinfeldt et al. 2012). Recent research also has identified HIF pathway candidate genes showing signatures of natural selection in other human populations, including Sherpa, Indians, and Mongolians (Aggarwal et al. 2010; Hanaoka et al. 2012; Kang et al. 2013; Xing et al. 2013; Jeong et al. 2014). 


\section{Tibetan adaptation to high altitude and genetic analyses}

Several studies have used genomic scans for positive selection among Tibetan highlanders to identify natural selection candidate loci (Beall et al. 2010; Bigham et al. 2010; Simonson et al. 2010; Yi et al. 2010; Peng et al. 2011a; Wang et al. 2011; Xu et al. 2011). Importantly, studies have shown evidence of natural selection among HIF pathway and hypoxia-related genes (Table 3B). Two genes are particularly noteworthy because of the consistency with which they have been observed in these studies (Simonson et al. 2012; Petousi and Robbins 2014). One is HIF2A, which shows evidence of positive directional selection (selection for advantageous mutations that increase fitness of carriers) in all of these genome-wide analyses (Beall et al. 2010; Bigham et al. 2010; Simonson et al. 2010; Yi et al. 2010; Peng et al. 2011a; Wang et al. 2011; Xu et al. 2011), and both HIF2A SNP genotypes and haplotypes significantly associate with low hemoglobin concentration in Tibetans (Beall et al. 2010; Yi et al. 2010). Intriguingly, a recent study suggests that introgression from Denisovan, a Homo species identified from remains found at Denisova Cave in the Altai Mountains of Siberia, or Denisova-related individuals is responsible for the Tibetan pattern of variation observed at this locus (Huerta-Sanchez et al. 2014), suggesting that ancient admixture may have contributed to potentially functionally important adaptive changes in the Tibetan genome.

A second HIF pathway candidate gene showing evidence of positive selection among Tibetans in multiple studies is PHD2 (Simonson et al. 2010; Yi et al. 2010; Peng et al. 2011a; Wang et al. 2011; Xu et al. 2011). Of note, the candidate genes identified for Andeans and Tibetans are largely distinct from one another, but PHD2 has emerged as a candidate for both populations. Further analysis reveals that among Tibetans, variants in this gene are associated with hemoglobin concentration, while among Andeans, they are not (Simonson et al. 2010; Bigham et al. 2013; Xiang et al. 2013). In the Tibetan population, two nonsynonymous coding variants located in exon1-rs12097901 (C127S) and rs186996510 (D4E)-have been observed at high frequency. The former is present at a frequency of 0.80.9 in Tibetans, as compared with $\sim 0.4-0.5$ in a control Han Chinese population (Xiang et al. 2013; Lorenzo et al. 2014; Petousi et al. 2014). The latter SNP displays an even more pronounced divergence, with a frequency of $0.6-0.9$ in Tibetans, and one of $\sim 0.01$ in Han Chinese (Xiang et al. 2013; Lorenzo et al. 2014; Petousi et al. 2014). Accordingly, this SNP (rs186996510) displays an $\mathrm{F}_{\mathrm{ST}}$ value between Tibetans and Han Chinese of 0.709, 70 times higher than that of the average of the chromosome in which it resides (Xiang et al. 2013). Two reports found that the two SNPs are in linkage disequilibrium (Lorenzo et al. 2014; Petousi et al. 2014), while a third study did not find them to be tightly linked (Xiang et al. 2013).

A key question now is how these genetic changes translate into adaptation. Lowlanders ordinarily maintain low levels of HIF-1 $\alpha$ and HIF- $2 \alpha$ through constitutive hydroxylation and degradation (Fig. 4, model A). Upon ascent to high altitude, attenuated PHD2 hydroxylase activity due to hypoxia leads to increased levels of HIF- $1 \alpha$ and HIF- $2 \alpha$ (and presumably HIF-3 $\alpha$ ) (Fig. 4, model B). In

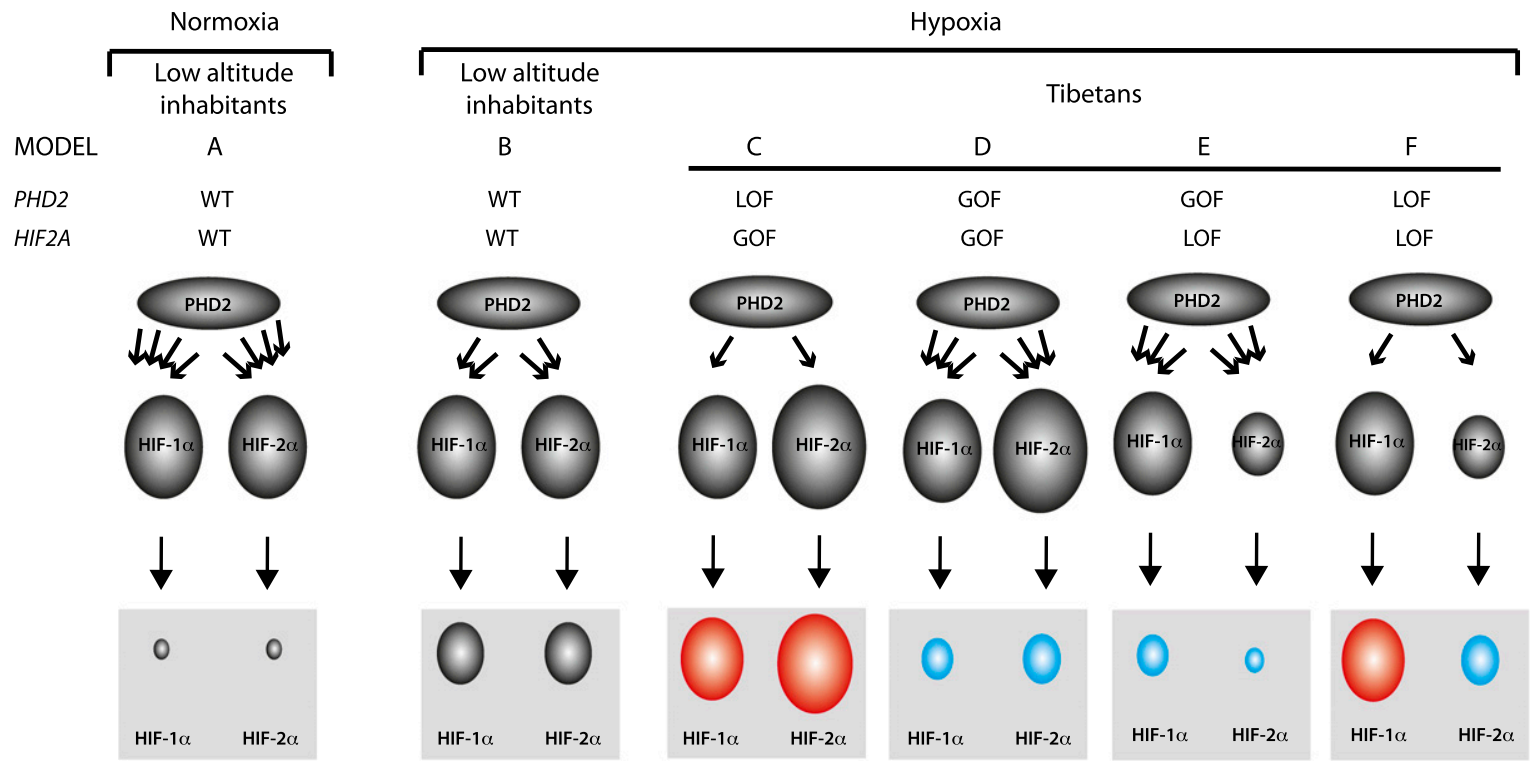

Figure 4. Models for high-altitude adaptation. (Model A) In lowlanders at low altitude, PHD2 constitutively hydroxylates (four arrows between PHD2 and HIF- $\alpha$ ) HIF- $\alpha$, leading to low levels of HIF- $\alpha$ (gray box). (Model B) In lowlanders who ascend to high altitude, PHD2 activity decreases (two arrows), leading to increased HIF- $\alpha$ levels (gray box). Models C-F show various combinations of GOF and LOF PHD2 and HIF2A alleles to potentially explain Tibetan adaptation. The number of arrows emanating from PHD2 indicates hydroxylase activity (one arrow: weak; three arrows: strong), and, immediately below it, the size of HIF-2 $\alpha$ indicates whether it is a GOF (larger) or LOF (smaller). The gray boxes at the bottom show the ultimate strength of HIF- $\alpha$ activation resulting from the combined PHD2 and HIF- $\alpha$ activity, with red denoting increased HIF- $\alpha$ activity relative to model B, and blue denoting decreased HIF- $\alpha$ activity relative to model B. 
simple terms, one could posit that the Tibetan PHD2 allele is either a GOF (enhanced hydroxylase) or LOF (diminished hydroxylase) allele and likewise that the Tibetan HIF2A allele is either a GOF (enhanced activity) or LOF (diminished activity) allele. This in turn leads to four models for Tibetan adaptation based on the PHD2: HIF axis (Fig. 4, models C-F). The PHD2 LOF:HIF2A GOF combination would be predicted to lead to enhanced HIF- $2 \alpha$ activity (Fig. 4, model C). A priori, this model seems unlikely given that this would be predicted to lead to elevated hemoglobin levels, the exact opposite of what is observed among Tibetans (Beall 2007). The remaining three models all could conceivably lead to lowered HIF- $2 \alpha$ activity.

For example, a PHD2 GOF:HIF2A GOF combination is possible if the $P H D 2$ allele is a relatively stronger GOF allele than the HIF2A allele is a GOF allele (Fig. 4, model D). Several observations, however, would seem to suggest that the HIF2A allele is more likely to be a LOF allele. (1) The Tibetan HIF2A allele, as mentioned previously, is correlated with low hemoglobin in several studies (Beall et al. 2010; Yi et al. 2010). (2) Lymphocytes isolated from Tibetans display low HIF2A mRNA levels (Petousi et al. 2014). If, indeed, the HIF2A allele was a LOF allele, it could provide an explanation for protection from pulmonary hypertension observed in Tibetans, since mice with haploinsufficiency at the Hif2a locus are protected from the pulmonary hypertension induced by hypoxia or the Chuvash LOF Vhl mutation as well as the erythrocytosis induced by the latter (Brusselmans et al. 2003; Hickey et al. 2010).

It cannot be overemphasized, however, that firm conclusions regarding the nature of this allele, including whether it is LOF or GOF, must await its molecular characterization. SNPs with high-frequency divergence between Tibetans and Han Chinese have been observed and all reside in noncoding (as opposed to coding) regions of the HIF2A gene (Yi et al. 2010; Peng et al. 2011a; Lorenzo et al. 2014). For example, intronic SNP rs150877473 has a frequency that rises from 0.09 in Han Chinese to 0.87 in Tibetans (Yi et al. 2010). Interestingly, this SNP changes a nucleotide in the vicinity of the $3^{\prime}$ splice site adjacent to exon 6 of the HIF2A gene and hence may functionally affect normal splicing of this gene. That being said, it should be noted that other groups have not identified Tibetan sequence variants at exon-intron boundaries; it should also be recognized that numerous other SNPs, located within introns or upstream of the HIF2A gene, display comparable degrees of divergence between Han Chinese and Tibetan populations (Peng et al. 2011a; Huerta-Sanchez et al. 2014; Lorenzo et al. 2014). It is conceivable that one or more of these is responsible for, or contributes to, the phenotype.

With regard to the PHD2 allele, a number of observations support the possibility that it is a GOF allele (Fig. 4, model E). (1) Several studies have examined potential associations between the Tibetan PHD2 allele and low hemoglobin concentration (Simonson et al. 2010; Xiang et al. 2013; Petousi et al. 2014), and correlations have been found in some, although not all, studies. (2) At low altitude, the Tibetan PHD2 allele is correlated with blunted plasma EPO response to hypoxia (Petousi et al. 2014). (3) Lymphocytes isolated from Tibetans display lowered hypoxic induction of select HIF-1 $\alpha$ and HIF- $2 \alpha$ target genes (Petousi et al. 2014). (4) Erythroid progenitors that carry the Tibetan PHD2 allele display impaired proliferation under hypoxic conditions (Lorenzo et al. 2014). Mechanistically, a GOF allele could arise from increased enzymatic activity of PHD2 toward HIF- $\alpha$, and, in support of this, it has been observed that Tibetan (D4E/C127S) PHD2 displays a lower $\mathrm{K}_{\mathrm{m}}$ for oxygen than wild-type PHD2 (Lorenzo et al. 2014). A GOF PHD2 allele, in conjunction with the LOF of the HIF2A allele, would be predicted to lead to hypoactivation of HIF- $\alpha$ and could readily provide an explanation for protection against not only erythrocytosis but also pulmonary hypertension, since both HIF- $1 \alpha$ and HIF- $2 \alpha$ have been implicated in the pathogenesis of the latter (Shimoda and Laurie 2014).

An alternative model is that the Tibetan PHD2 allele is a LOF allele, which is supported by the observations that (1) erythroid progenitors that are homozygous for the Tibetan PHD2 allele display EPO hypersensitivity under normoxic conditions, and (2) granulocytes isolated from Tibetans display increased expression of select HIF target genes (Lorenzo et al. 2014). A Tibetan PHD2 LOF allele would necessarily imply that the HIF2A allele is a strong LOF allele, leading ultimately to activation of HIF- $1 \alpha$ and inhibition of HIF-2 $\alpha$ (Fig. 4, model F). It has been observed that the Tibetan (D4E/C127S) PHD2 is markedly defective in its interaction with p23 (Song et al. 2014), which would support this model. Interestingly, the defective interaction depends on both the D4E and C127S substitutions (Song et al. 2014) and therefore is consistent with the linkage disequilibrium that has been observed for the two SNPs that encode these substitutions (Lorenzo et al. 2014; Petousi et al. 2014). This model could conceivably provide an explanation for the increased respiratory drive observed in Tibetans. For example, it has been observed that mice that are heterozygous for either a knockout Phd2 allele or a knock-in LOF (P294R) Phd2 allele display increased respiratory drive (Arsenault et al. 2013; Bishop et al. 2013). Conversely, mice that are haploinsufficient at the Hif1a locus display a blunted HVR following chronic hypoxia (Kline et al. 2002; Peng et al. 2006). Taken together, this suggests an important role for the PHD2: HIF- $1 \alpha$ axis in controlling respiratory drive. A LOF PHD2 allele also may contribute to the increased NO levels, since NOS2 (iNOS) is a well-characterized HIF- $1 \alpha$ target gene (Takeda et al. 2010).

At the same time, however, a LOF allele might be predicted to predispose to pulmonary hypertension and exacerbate the erythrocytosis that can be seen at high altitude. The following considerations might mitigate against this. First, patients with heterozygous LOF PHD2 mutations do not typically present with pulmonary hypertension, nor do the mice with the heterozygous LOF knockin (P294R) mutation at the Phd2 locus (Lee and Percy 2011; Arsenault et al. 2013). This might be contrasted with humans and mice with GOF mutations in the HIF2A gene, in which heterozygosity is sufficient to induce pulmonary hypertension (Gale et al. 2008; Tan et al. 2013). Second and 
importantly, Tibetans may be protected from both erythrocytosis and pulmonary hypertension by the high-frequency Tibetan HIF2A allele previously discussed.

With regard to the latter, the timing of the appearance of the Tibetan HIF2A and PHD2 alleles becomes an issue of importance. Estimates for the emergence of the HIF2A allele have been controversial. One study proposed that it may have arisen as recently as 3000 years ago (Yi et al. 2010). However, another group estimated that it arose $\sim 18,000$ years ago (Peng et al. 2011a), and this same group proposed that the PHD2 allele arose subsequently $\sim 8000$ years ago; this latter estimate is also consistent with an independent study that placed its emergence at 8000 years (Lorenzo et al. 2014). If, indeed, the Tibetan HIF2A allele preceded the PHD2 allele, then potentially deleterious effects of the latter may have been blunted by a preexisting high-frequency protective HIF2A allele.

Beyond these considerations, there are yet other factors that may introduce additional complexities into the models presented in Figure 4. First, the Tibetan PHD2 variant may be differentially defective in the capacity to promote degradation of HIF- $1 \alpha$ versus HIF- $2 \alpha$. Second, the function of the zinc finger in PHD2 may vary in importance in a tissue-specific manner. Third, the zinc finger of PHD2 may differentially use the PXLE motifs of p23, FKBP38, and HSP90; in this regard, it should be noted that the D4E/C127S substitution maintains zinc finger interaction with FKBP38 and HSP90, albeit somewhat more weakly (Song et al. 2014). Fourth, PHD2 is deployed in a tissue-specific manner, and the presence of two other PHD paralogs with potentially redundant activity with PHD2 will undoubtedly modulate the impact of PHD2 LOF or GOF. For example, loss of murine $P h d 2$ alone in the Epo-producing cells of the kidney, hematopoietic precursors, cardiomyocytes, or hepatocytes is sufficient to produce a phenotype (erythrocytosis in the first two cases, cardiomyopathy in the third case, and activation of Hif- $1 \alpha$ in the last), indicating that the other two PHD paralogs cannot suppress Hif- $\alpha$ to normal levels in these tissues (Table 2; Minamishima et al. 2008; Takeda et al. 2008; Moslehi et al. 2010; Arsenault et al. 2013; Taniguchi et al. 2013). On the other hand, studies also indicate that loss of Phd2 alone in the liver or in osteoblasts does not produce erythrocytosis, whereas concurrent loss of Phd1 and Phd3 does, indicating that all three Phd paralogs contribute to normal Hif- $2 \alpha$ suppression in these tissues (Minamishima and Kaelin 2010; Rankin et al. 2012; Duan et al. 2014). Taken together, these observations indicate that the phenotypic consequences of PHD2 LOF will manifest in a tissue-specific manner. It is likely that the same would hold for PHD2 GOF mutations. It will clearly be of interest to determine whether any of the aforementioned mechanisms, or perhaps some other mechanism, accounts for the Tibetan PHD2 haplotype.

\section{Perspectives}

It should be apparent from this discussion that the mechanisms of high-altitude adaptation in different human populations are distinct and undoubtedly complex.
Furthermore, mounting evidence suggests that the observed physiological adaptations are controlled by interactions among multiple genes, especially those that are part of the HIF pathway. The Tibetan population shows the strongest support that multiple genes in the HIF pathway have been reconfigured in response to chronic hypoxia. This interaction of genes determining highaltitude-adaptive phenotypes may be contrasted with other well-known examples of recent human evolution in which selection appears to have acted on single genes. Examples of this would include the selection of a Lactase $(L C T)$ gene variant to allow lactase persistence in European populations and the selection of an EDAR variant to produce a constellation of findings related to ectodermal development in Asian populations (Kamberov et al. 2013; Scheinfeldt and Tishkoff 2013). High-altitude adaptation may be more like skin color determination, in which multiple interacting loci determine phenotype (Sturm 2009).

The continued study of high-altitude adaptation may provide the basis for new therapies for diseases characterized by ischemia and chronic hypoxia. In the Tibetan population, the changes in the PHD2 and HIF2A genes were selected over the course of thousands of years, providing proof of principle of their efficacy. However, challenges remain if we are to extrapolate the highaltitude findings to low-altitude, hypoxic disease states. For example, it may be necessary to target both PHD2 and HIF- $2 \alpha$ in order to phenocopy Tibetan adaptation. This is within the realm of possibility, since there are many examples of drug combinations that concurrently target enzymes/proteins in the same pathway to achieve a beneficial effect (e.g., amoxicillin/clavulinic acid). Moreover, while it is likely that selection of HIF pathway genes in Tibetans is mainly a reflection of adaptation to chronic hypoxia, genetic changes in this population as well as other high-altitude groups may reflect adaptation to other environmental stresses present at high altitude, such as low temperature and increased UV exposure.

Human high-altitude adaptation has drawn the attention of molecular biologists, anthropologists, geneticists, and physiologists alike. It is an excellent natural experiment design in which to study the evolutionary process. By understanding how similar environmental pressures can result in either the same or different genetic adaptations, we will be better situated to understand the molecular basis for convergent human adaptations. Continued study is paramount in order to elucidate genotype-phenotype correlations and provide molecular explanations for highaltitude adaptation. We are at an early stage of this research, and much remains to be learned from these remarkable experiments of nature.

\section{Acknowledgments}

Work in F.S.L.'s laboratory has been supported by National Institutes of Health grants R21-HL120751, R01-CA153347, and R01-GM090301. Work in A.W.B.'s laboratory has been supported by National Science Foundation grant BCS-1132310 and The University of Michigan. 


\section{References}

Acevedo JM, Centanin L, Dekanty A, Wappner P. 2010. Oxygen sensing in Drosophila: multiple isoforms of the prolyl hydroxylase fatiga have different capacity to regulate $\mathrm{HIF} \alpha / \mathrm{Sima}$. PLOS ONE 5: e12390.

Adams WH, Strang LJ. 1975. Hemoglobin levels in persons of Tibetan ancestry living at high altitude. Proc Soc Exp Biol Med 149: 1036-1039.

Aggarwal S, Negi S, Jha P, Singh PK, Stobdan T, Pasha MA, Ghosh S, Agrawal A, Prasher B, Mukerii M. 2010. EGLN1 involvement in high-altitude adaptation revealed through genetic analysis of extreme constitution types defined in Ayurveda. Proc Natl Acad Sci 107: 18961-18966.

Al-Sheikh M, Moradkhani K, Lopez M, Wajcman H, Prehu C. 2008. Disturbance in the HIF-1 $\alpha$ pathway associated with erythrocytosis: further evidences brought by frameshift and nonsense mutations in the prolyl hydroxylase domain protein 2 (PHD2) gene. Blood Cells Mol Dis 40: 160-165.

Anderson ER, Xue X, Shah YM. 2011. Intestinal hypoxia-inducible factor- $2 \alpha$ (HIF-2 $\alpha$ ) is critical for efficient erythropoiesis. I Biol Chem 286: 19533-19540.

Appelhoff RJ, Tian YM, Raval RR, Turley H, Harris AL, Pugh CW, Ratcliffe PJ, Gleadle JM. 2004. Differential function of the prolyl hydroxylases PHD1, PHD2, and PHD3 in the regulation of hypoxia-inducible factor. I Biol Chem 279: 38458-38465.

Arias-Stella J, Saldana M. 1962. The muscular pulmonary arteries in people native to high altitude. Med Thorac 19: 484-493.

Arsenault PR, Pei F, Lee R, Kerestes H, Percy MJ, Keith B, Simon MC, Lappin TR, Khurana TS, Lee FS. 2013. A knock-in mouse model of human PHD2 gene-associated erythrocytosis establishes a haploinsufficiency mechanism. J Biol Chem 288: 33571-33584.

Barth S, Nesper J, Hasgall PA, Wirthner R, Nytko KJ, Edlich F, Katschinski DM, Stiehl DP, Wenger RH, Camenisch G. 2007. The peptidyl prolyl cis/trans isomerase FKBP38 determines hypoxia-inducible transcription factor prolyl-4-hydroxylase PHD2 protein stability. Mol Cell Biol 27: 3758-3768.

Beall CM. 2006. Andean, Tibetan, and Ethiopian patterns of adaptation to high-altitude hypoxia. Integr Comp Biol 46: $18-24$.

Beall CM. 2007. Two routes to functional adaptation: Tibetan and Andean high-altitude natives. Proc Natl Acad Sci 104: 8655-8660.

Beall CM. 2013. Human adaptability studies at high altitude: research designs and major concepts during fifty years of discovery. Am I Hum Biol 25: 141-147.

Beall CM, Goldstein MC. 1987. Hemoglobin concentration of pastoral nomads permanently resident at 4,850-5,450 meters in Tibet. Am I Phys Anthropol 73: 433-438.

Beall CM, Reichsman AB. 1984. Hemoglobin levels in a Himalayan high altitude population. Am I Phys Anthropol 63: 301-306.

Beall CM, Brittenham GM, Macuaga F, Barragan M. 1990. Variation in hemoglobin concentration among samples of high-altitude natives in the Andes and the Himalayas. Am I Hum Biol 2: 639-651.

Beall CM, Blangero J, Williams-Blangero S, Goldstein MC. 1994. Major gene for percent of oxygen saturation of arterial hemoglobin in Tibetan highlanders. Am I Phys Anthropol 95: 271-276.

Beall CM, Strohl KP, Blangero J, Williams-Blangero S, Almasy LA, Decker MJ, Worthman CM, Goldstein MC, Vargas E, Villena M, et al. 1997a. Ventilation and hypoxic ventilatory response of
Tibetan and Aymara high altitude natives. Am J Phys Anthropol 104: 427-447.

Beall CM, Strohl KP, Blangero J, Williams-Blangero S, Decker MJ, Brittenham GM, Goldstein MC. 1997b. Quantitative genetic analysis of arterial oxygen saturation in Tibetan highlanders. Hum Biol 69: 597-604.

Beall CM, Brittenham GM, Strohl KP, Blangero J, WilliamsBlangero S, Goldstein MC, Decker MJ, Vargas E, Villena M, Soria R, et al. 1998. Hemoglobin concentration of highaltitude Tibetans and Bolivian Aymara. Am J Phys Anthropol 106: 385-400.

Beall CM, Almasy LA, Blangero J, Williams-Blangero S, Brittenham GM, Strohl KP, Decker MJ, Vargas E, Villena M, Soria R, et al. 1999. Percent of oxygen saturation of arterial hemoglobin among Bolivian Aymara at 3,900-4,000 m. Am J Phys Anthropol 108: 41-51.

Beall CM, Decker MJ, Brittenham GM, Kushner I, Gebremedhin A, Strohl KP. 2002. An Ethiopian pattern of human adaptation to high-altitude hypoxia. Proc Natl Acad Sci 99: 1721517218.

Beall CM, Cavalleri GL, Deng L, Elston RC, Gao Y, Knight J, Li C, Li JC, Liang Y, McCormack M, et al. 2010. Natural selection on EPAS1 (HIF2 $\alpha$ ) associated with low hemoglobin concentration in Tibetan highlanders. Proc Natl Acad Sci 107: 11459-11464.

Beall CM, Laskowski D, Erzurum SC. 2012. Nitric oxide in adaptation to altitude. Free Radic Biol Med 52: 1123-1134.

Bennett A, Sain SR, Vargas E, Moore LG. 2008. Evidence that parent-of-origin affects birth-weight reductions at high altitude. Am J Hum Biol 20: 592-597.

Berra E, Benizri E, Ginouves A, Volmat V, Roux D, Pouyssegur J. 2003. HIF prolyl-hydroxylase 2 is the key oxygen sensor setting low steady-state levels of HIF- $1 \alpha$ in normoxia. EMBO J 22: 4082-4090.

Bigham A. 2008. "Evidence for natural selection in high altitude human populations." $\mathrm{PhD}$ thesis. Pennsylvania State University. University Park, PA.

Bigham AW, Mao X, Mei R, Brutsaert T, Wilson MJ, Julian CG, Parra EJ, Akey JM, Moore LG, Shriver MD. 2009. Identifying positive selection candidate loci for high-altitude adaptation in Andean populations. Hum Genomics 4: 79-90.

Bigham A, Bauchet M, Pinto D, Mao X, Akey JM, Mei R, Scherer SW, Julian CG, Wilson MJ, Lopez Herraez D, et al. 2010. Identifying signatures of natural selection in Tibetan and Andean populations using dense genome scan data. PLoS Genet 6: e1001116.

Bigham AW, Wilson MJ, Julian CG, Kiyamu M, Vargas E, LeonVelarde F, Rivera-Chira M, Rodriquez C, Browne VA, Parra E, et al. 2013. Andean and Tibetan patterns of adaptation to high altitude. Am J Hum Biol 25: 190-197.

Bigham AW, Julian CG, Wilson MJ, Vargas E, Browne VA, Shriver MD, Moore LG. 2014. Maternal PRKAA1 and EDNRA genotypes are associated with birth weight, and PRKAAl with uterine artery diameter and metabolic homeostasis at high altitude. Physiol Genomics 46: 687-697.

Bishop T, Talbot NP, Turner PJ, Nicholls LG, Pascual A, Hodson EJ, Douglas G, Fielding JW, Smith TG, Demetriades M, et al. 2013. Carotid body hyperplasia and enhanced ventilatory responses to hypoxia in mice with heterozygous deficiency of PHD2. J Physiol 591: 3565-3577.

Branco-Price C, Zhang N, Schnelle M, Evans C, Katschinski DM, Liao D, Ellies L, Johnson RS. 2012. Endothelial cell HIF$1 \alpha$ and HIF- $2 \alpha$ differentially regulate metastatic success. Cancer Cell 21: 52-65.

Bruick RK, McKnight SL. 2001. A conserved family of prolyl-4hydroxylases that modify HIF. Science 294: 1337-1340. 
Brusselmans K, Compernolle V, Tjwa M, Wiesener MS, Maxwell PH, Collen D, Carmeliet P. 2003. Heterozygous deficiency of hypoxia-inducible factor- $2 \alpha$ protects mice against pulmonary hypertension and right ventricular dysfunction during prolonged hypoxia. J Clin Invest 111: 1519-1527.

Brutsaert TD, Araoz M, Soria R, Spielvogel H, Haas JD. 2000. Higher arterial oxygen saturation during submaximal exercise in Bolivian Aymara compared to European sojourners and Europeans born and raised at high altitude. Am I Phys Anthropol 113: 169-181.

Brutsaert TD, Parra EJ, Shriver MD, Gamboa A, Rivera-Ch M, Leon-Velarde F. 2005. Ancestry explains the blunted ventilatory response to sustained hypoxia and lower exercise ventilation of Quechua altitude natives. Am I Physiol Regul Integr Comp Physiol 289: R225-R234.

Chiodi H. 1957. Respiratory adaptations to chronic high altitude hypoxia. J Appl Physiol 10: 81-87.

Cho YS, Hu L, Hou H, Lee H, Xu J, Kwon S, Oh S, Kim HM, Jho S, Kim S, et al. 2013. The tiger genome and comparative analysis with lion and snow leopard genomes. Nat Commun 4: 2433.

Choi KO, Lee T, Lee N, Kim JH, Yang EG, Yoon JM, Kim JH, Lee TG, Park H. 2005. Inhibition of the catalytic activity of hypoxiainducible factor- $1 \alpha$-prolyl-hydroxylase 2 by a MYND-type zinc finger. Mol Pharmacol 68: 1803-1809.

Cowburn AS, Takeda N, Boutin AT, Kim JW, Sterling JC, Nakasaki M, Southwood M, Goldrath AW, Jamora C, Nizet V, et al. 2013. HIF isoforms in the skin differentially regulate systemic arterial pressure. Proc Natl Acad Sci 110: 1757017575.

Cueto M. 1986. Andean biology in Peru: scientific styles on the periphery. Isis 80: 640-658.

Dempsey JA, Reddan WG, Birnbaum ML, Forster HV, Thoden JS, Grover RF, Rankin J. 1971. Effects of acute through lifelong hypoxic exposure on exercise pulmonary gas exchange. Respir Physiol 13: 62-89.

Duan LJ, Takeda K, Fong GH. 2014. Hematological, hepatic, and retinal phenotypes in mice deficient for prolyl hydroxylase domain proteins in the liver. Am J Pathol 184: 1240-1250.

Ehrismann D, Flashman E, Genn DN, Mathioudakis N, Hewitson KS, Ratcliffe PJ, Schofield CJ. 2007. Studies on the activity of the hypoxia-inducible-factor hydroxylases using an oxygen consumption assay. Biochem J 401: 227-234.

Epstein AC, Gleadle JM, McNeill LA, Hewitson KS, O'Rourke J, Mole DR, Mukherii M, Metzen E, Wilson MI, Dhanda A, et al. 2001. C. elegans EGL-9 and mammalian homologs define a family of dioxygenases that regulate HIF by prolyl hydroxylation. Cell 107: 43-54.

Erzurum SC, Ghosh S, Janocha AJ, Xu W, Bauer S, Bryan NS, Tejero J, Hemann C, Hille R, Stuehr DJ, et al. 2007. Higher blood flow and circulating NO products offset high-altitude hypoxia among Tibetans. Proc Natl Acad Sci 104: 1759317598 .

Fan Z, Zhao G, Li P, Osada N, Xing J, Yi Y, Du L, Silva P, Wang H, Sakate R, et al. 2014. Whole-genome sequencing of Tibetan Macaque (Macaca thibetana) provides new insight into the Macaque evolutionary history. Mol Biol Evol 31: 14751489.

Ferguson AD, Larsen NA, Howard T, Pollard H, Green I, Grande C, Cheung T, Garcia-Arenas R, Cowen S, Wu J, et al. 2011. Structural basis of substrate methylation and inhibition of SMYD2. Structure 19: 1262-1273.

Franke K, Kalucka J, Mamlouk S, Singh RP, Muschter A, Weidemann A, Iyengar V, Jahn S, Wieczorek K, Geiger K, et al. 2013. HIF- $1 \alpha$ is a protective factor in conditional PHD2-deficient mice suffering from severe HIF- $2 \alpha$-induced excessive erythropoiesis. Blood 121: 1436-1445.
Frisancho AR, Frisancho HG, Milotich M, Brutsaert T, Albalak R, Spielvogel H, Villena M, Vargas E, Soria R. 1995. Developmental, genetic, and environmental components of aerobic capacity at high altitude. Am I Phys Anthropol 96: 431-442.

Furlow PW, Percy MJ, Sutherland S, Bierl C, McMullin MF, Master SR, Lappin TR, Lee FS. 2009. Erythrocytosis-associated HIF- $\alpha$ mutations demonstrate a critical role for residues C-terminal to the hydroxylacceptor proline. I Biol Chem 284: 9050-9058.

Gale DP, Harten SK, Reid CD, Tuddenham EG, Maxwell PH. 2008. Autosomal dominant erythrocytosis and pulmonary arterial hypertension associated with an activating HIF $2 \alpha$ mutation. Blood 112: 919-921.

Gardie B, Percy MJ, Hoogewijs D, Chowdhury R, Bento C, Arsenault PR, Richard S, Almeida H, Ewing I, Lambert F, et al. 2014. The role of PHD2 mutations in the pathogenesis of erythrocytosis. Hypoxia (Auckl) 2: 71-90.

Ge RL, Chen QH, He LG. 1994. [Characteristics of hypoxic ventilatory response in Tibetan living at moderate and high altitudes]. Zhonghua Jie He He Hu Xi Za Zhi 17: 364-366, 384.

Ge RL, Cai Q, Shen YY, San A, Ma L, Zhang Y, Yi X, Chen Y, Yang L, Huang Y, et al. 2013. Draft genome sequence of the Tibetan antelope. Nat Commun 4: 1858.

Giaccia A, Siim BG, Johnson RS. 2003. HIF-1 as a target for drug development. Nat Rev Drug Discov 2: 803-811.

Greer SN, Metcalf JL, Wang Y, Ohh M. 2012. The updated biology of hypoxia-inducible factor. EMBO J 31: 2448-2460.

Groves BM, Droma T, Sutton JR, McCullough RG, McCullough RE, Zhuang J, Rapmund G, Sun S, Janes C, Moore LG. 1993. Minimal hypoxic pulmonary hypertension in normal Tibetans at 3,658 m. I Appl Physiol 74: 312-318.

Gruber M, Hu CJ, Johnson RS, Brown EJ, Keith B, Simon MC. 2007. Acute postnatal ablation of Hif- $2 \alpha$ results in anemia. Proc Natl Acad Sci 104: 2301-2306.

Hanaoka M, Droma Y, Basnyat B, Ito M, Kobayashi N, Katsuyama Y, Kubo K, Ota M. 2012. Genetic variants in EPAS1 contribute to adaptation to high-altitude hypoxia in Sherpas. PLOS ONE 7: e50566.

Hewitson KS, McNeill LA, Riordan MV, Tian YM, Bullock AN, Welford RW, Elkins JM, Oldham NJ, Bhattacharya S, Gleadle JM, et al. 2002. Hypoxia-inducible factor (HIF) asparagine hydroxylase is identical to factor inhibiting $\mathrm{HIF}(\mathrm{FIH})$ and is related to the cupin structural family. J Biol Chem 277: 26351-26355.

Hickey MM, Richardson T, Wang T, Mosqueira M, Arguiri E, Yu H, Yu QC, Solomides CC, Morrisey EE, Khurana TS, et al. 2010. The von Hippel-Lindau Chuvash mutation promotes pulmonary hypertension and fibrosis in mice. I Clin Invest 120: 827839.

Hirsila M, Koivunen P, Gunzler V, Kivirikko KI, Myllyharju J. 2003. Characterization of the human prolyl 4-hydroxylases that modify the hypoxia-inducible factor. I Biol Chem 278: 30772-30780.

Holscher M, Silter M, Krull S, von Ahlen M, Hesse A, Schwartz P, Wielockx B, Breier G, Katschinski DM, Zieseniss A. 2011. Cardiomyocyte-specific prolyl-4-hydroxylase domain 2 knock out protects from acute myocardial ischemic injury. I Biol Chem 286: 11185-11194.

Hornbein TF, Schoene RB. 2001. High altitude: an exploration of human adaptation. Marcel Dekker, New York.

Huerta-Sanchez E, Degiorgio M, Pagani L, Tarekegn A, Ekong R, Antao T, Cardona A, Montgomery HE, Cavalleri GL, Robbins PA, et al. 2013. Genetic signatures reveal high-altitude adaptation in a set of ethiopian populations. Mol Biol Evol 30: 1877-1888.

Huerta-Sanchez E, Jin X. Asan, Bianba Z, Peter BM, Vinckenbosch N, Liang Y, Yi X, He M, Somel M, et al. 2014. Altitude adaptation in 
Tibetans caused by introgression of Denisovan-like DNA. Nature: 512: 194-197.

Isaacs JS, Jung YJ, Mimnaugh EG, Martinez A, Cuttitta F, Neckers LM. 2002. Hsp90 regulates a von Hippel Lindauindependent hypoxia-inducible factor- $1 \alpha$-degradative pathway. I Biol Chem 277: 29936-29944.

Ivan M, Kondo K, Yang H, Kim W, Valiando J, Ohh M, Salic A, Asara JM, Lane WS, Kaelin WG Jr. 2001. HIF $\alpha$ targeted for VHL-mediated destruction by proline hydroxylation: implications for $\mathrm{O}_{2}$ sensing. Science 292: 464-468.

Ivan M, Haberberger T, Gervasi DC, Michelson KS, Gunzler V, Kondo K, Yang H, Sorokina I, Conaway RC, Conaway JW, et al. 2002. Biochemical purification and pharmacological inhibition of a mammalian prolyl hydroxylase acting on hypoxia-inducible factor. Proc Natl Acad Sci 99: 1345913464.

Jaakkola P, Mole DR, Tian YM, Wilson MI, Gielbert J, Gaskell SJ, Kriegsheim Av A, Hebestreit HF, Mukherji M, Schofield CJ, et al. 2001. Targeting of HIF- $\alpha$ to the von Hippel-Lindau ubiquitylation complex by $\mathrm{O}_{2}$-regulated prolyl hydroxylation. Science 292: 468-472.

Jeong C, Alkorta-Aranburu G, Basnyat B, Neupane M, Witonsky DB, Pritchard JK, Beall CM, Di Rienzo A. 2014. Admixture facilitates genetic adaptations to high altitude in Tibet. Nat Commun 5: 3281.

Julian CG, Vargas E, Armaza JF, Wilson MJ, Niermeyer S, Moore LG. 2007. High-altitude ancestry protects against hypoxiaassociated reductions in fetal growth. Arch Dis Child Fetal Neonatal Ed 92: F372-F377.

Kaelin WG Jr, Ratcliffe PJ. 2008. Oxygen sensing by metazoans: the central role of the HIF hydroxylase pathway. Mol Cell 30: 393-402.

Kamberov YG, Wang S, Tan J, Gerbault P, Wark A, Tan L, Yang Y, Li S, Tang K, Chen H, et al. 2013. Modeling recent human evolution in mice by expression of a selected EDAR variant. Cell 152: 691-702.

Kang L, Zheng HX, Chen F, Yan S, Liu K, Qin Z, Liu L, Zhao Z, Li L, Wang $X$, et al. 2013. mtDNA lineage expansions in Sherpa population suggest adaptive evolution in Tibetan highlands. Mol Biol Evol 30: 2579-2587.

Kapitsinou PP, Haase VH. 2008. The VHL tumor suppressor and HIF: insights from genetic studies in mice. Cell Death Differ 15: 650-659.

Kapitsinou PP, Liu Q, Unger TL, Rha J, Davidoff O, Keith B, Epstein JA, Moores SL, Erickson-Miller CL, Haase VH. 2010. Hepatic HIF-2 regulates erythropoietic responses to hypoxia in renal anemia. Blood 116: 3039-3048.

Katschinski DM, Le L, Heinrich D, Wagner KF, Hofer T, Schindler SG, Wenger RH. 2002. Heat induction of the unphosphorylated form of hypoxia-inducible factor- $1 \alpha$ is dependent on heat shock protein-90 activity. I Biol Chem 277: 9262-9267.

Keith B, Johnson RS, Simon MC. 2012. HIF1 $\alpha$ and HIF2 $\alpha$ : sibling rivalry in hypoxic tumour growth and progression. Nat ReV Cancer 12: 9-22.

Kerkela R, Karsikas S, Szabo Z, Serpi R, Magga J, Gao E, Alitalo K, Anisimov A, Sormunen R, Pietila I, et al. 2013. Activation of hypoxia response in endothelial cells contributes to ischemic cardioprotection. Mol Cell Biol 33: 33213329.

Kim JW, Tchernyshyov I, Semenza GL, Dang CV. 2006a. HIF-1mediated expression of pyruvate dehydrogenase kinase: a metabolic switch required for cellular adaptation to hypoxia. Cell Metab 3: 177-185.

Kim WY, Safran M, Buckley MR, Ebert BL, Glickman J, Bosenberg M, Regan M, Kaelin WG Jr. 2006b. Failure to prolyl hydroxylate hypoxia-inducible factor $\alpha$ phenocopies VHL inactivation in vivo. EMBO J 25: 4650-4662.

Kim EB, Fang X, Fushan AA, Huang Z, Lobanov AV, Han L, Marino SM, Sun X, Turanov AA, Yang P, et al. 2011. Genome sequencing reveals insights into physiology and longevity of the naked mole rat. Nature 479: 223-227.

Kline DD, Peng YJ, Manalo DJ, Semenza GL, Prabhakar NR. 2002. Defective carotid body function and impaired ventilatory responses to chronic hypoxia in mice partially deficient for hypoxia-inducible factor $1 \alpha$. Proc Natl Acad Sci 99: 821826.

Koivunen P, Hirsila M, Gunzler V, Kivirikko KI, Myllyharju J. 2004. Catalytic properties of the asparaginyl hydroxylase (FIH) in the oxygen sensing pathway are distinct from those of its prolyl 4-hydroxylases. I Biol Chem 279: 9899-9904.

Ladroue C, Carcenac R, Leporrier M, Gad S, Le Hello C, Galateau-Salle F, Feunteun J, Pouyssegur I, Richard S, Gardie B. 2008. PHD2 mutation and congenital erythrocytosis with paraganglioma. $N$ Engl J Med 359: 2685-2692.

Lando D, Peet DJ, Gorman JJ, Whelan DA, Whitelaw ML, Bruick RK. 2002a. FIH-1 is an asparaginyl hydroxylase enzyme that regulates the transcriptional activity of hypoxia-inducible factor. Genes Dev 16: 1466-1471.

Lando D, Peet DJ, Whelan DA, Gorman JJ, Whitelaw ML. 2002b. Asparagine hydroxylation of the HIF transactivation domain a hypoxic switch. Science 295: 858-861.

Lee FS, Percy MJ. 2011. The HIF pathway and erythrocytosis. Annu Rev Pathol 6: 165-192.

Lei L, Mason S, Liu D, Huang Y, Marks C, Hickey R, Jovin IS, Pypaert M, Johnson RS, Giordano FJ. 2008. Hypoxia-inducible factor-dependent degeneration, failure, and malignant transformation of the heart in the absence of the von HippelLindau protein. Mol Cell Biol 28: 3790-3803.

Lendahl U, Lee KL, Yang H, Poellinger L. 2009. Generating specificity and diversity in the transcriptional response to hypoxia. Nat Rev Genet 10: 821-832.

Li X, Sutherland S, Takeda K, Fong GH, Lee FS. 2010. Integrity of the prolyl hydroxylase domain protein 2:erythropoietin pathway in aging mice. Blood Cells Mol Dis 45: 9-19.

Li M, Tian S, Jin L, Zhou G, Li Y, Zhang Y, Wang T, Yeung CK, Chen L, Ma J, et al. 2013. Genomic analyses identify distinct patterns of selection in domesticated pigs and Tibetan wild boars. Nat Genet 45: 1431-1438.

Loenarz C, Coleman ML, Boleininger A, Schierwater B, Holland PW, Ratcliffe PJ, Schofield CJ. 2011. The hypoxia-inducible transcription factor pathway regulates oxygen sensing in the simplest animal, Trichoplax adhaerens. EMBO Rep 12: 6370.

Lorenzo FR, Huff C, Myllymaki M, Olenchock B, Swierczek S, Tashi T, Gordeuk V, Wuren T, Ri-Li G, McClain DA, et al. 2014. A genetic mechanism for Tibetan high-altitude adaptation. Nat Genet 46: 951-956.

Majmundar AJ, Wong WJ, Simon MC. 2010. Hypoxia-inducible factors and the response to hypoxic stress. Mol Cell 40: 294309.

Makino Y, Cao R, Svensson K, Bertilsson G, Asman M, Tanaka H, Cao Y, Berkenstam A, Poellinger L. 2001. Inhibitory PAS domain protein is a negative regulator of hypoxia-inducible gene expression. Nature 414: 550-554.

Mason SD, Howlett RA, Kim MJ, Olfert IM, Hogan MC, McNulty W, Hickey RP, Wagner PD, Kahn CR, Giordano FJ, et al. 2004. Loss of skeletal muscle HIF-1 $\alpha$ results in altered exercise endurance. PLoS Biol 2: e288.

Mason SD, Rundqvist H, Papandreou I, Duh R, McNulty WJ, Howlett RA, Olfert IM, Sundberg CJ, Denko NC, Poellinger L, et al. 2007. HIF-1 $\alpha$ in endurance training: suppression of 
oxidative metabolism. Am I Physiol Regul Integr Comp Physiol 293: R2059-R2069.

Masson N, Willam C, Maxwell PH, Pugh CW, Ratcliffe PJ. 2001. Independent function of two destruction domains in hypoxia-inducible factor- $\alpha$ chains activated by prolyl hydroxylation. EMBO J 20: 5197-5206.

Mastrogiannaki M, Matak P, Keith B, Simon MC, Vaulont S, Peyssonnaux C. 2009. HIF-2 $\alpha$, but not HIF- $1 \alpha$, promotes iron absorption in mice. J Clin Invest 119: 1159-1166.

Matthews JM, Bhati M, Lehtomaki E, Mansfield RE, Cubeddu L, Mackay JP. 2009. It takes two to tango: the structure and function of LIM, RING, PHD and MYND domains. Curr Pharm Des 15: 3681-3696.

Maynard MA, Qi H, Chung J, Lee EH, Kondo Y, Hara S, Conaway RC, Conaway JW, Ohh M. 2003. Multiple splice variants of the human HIF- $3 \alpha$ locus are targets of the von Hippel-Lindau E3 ubiquitin ligase complex. J Biol Chem 278: 11032-11040.

Mazzone M, Dettori D, Leite de Oliveira R, Loges S, Schmidt T, Jonckx B, Tian YM, Lanahan AA, Pollard P, Ruiz de Almodovar C, et al. 2009. Heterozygous deficiency of PHD2 restores tumor oxygenation and inhibits metastasis via endothelial normalization. Cell 136: 839-851.

McDonough MA, Loenarz C, Chowdhury R, Clifton IJ, Schofield CJ. 2010. Structural studies on human 2-oxoglutarate dependent oxygenases. Curr Opin Struct Biol 20: 659-672.

Mennerich D, Kietzmann T. 2014. Direct phosphorylation events involved in HIF- $\alpha$ regulation: the role of GSK- $3 \beta$. Hypoxia (Auckl) 2: 35-45.

Minamishima YA, Kaelin WG Jr. 2010. Reactivation of hepatic EPO synthesis in mice after PHD loss. Science 329: 407.

Minamishima YA, Moslehi J, Bardeesy N, Cullen D, Bronson RT, Kaelin WG Jr. 2008. Somatic inactivation of the PHD2 prolyl hydroxylase causes polycythemia and congestive heart failure. Blood 111: 3236-3244.

Minamishima YA, Moslehi J, Padera RF, Bronson RT, Liao R, Kaelin WG Jr. 2009. A feedback loop involving the Phd3 prolyl hydroxylase tunes the mammalian hypoxic response in vivo. Mol Cell Biol 29: 5729-5741.

Minet E, Mottet D, Michel G, Roland I, Raes M, Remacle J, Michiels C. 1999. Hypoxia-induced activation of HIF-1: role of HIF-1 $\alpha$-Hsp90 interaction. FEBS Lett 460: 251-256.

Mole DR, Blancher C, Copley RR, Pollard PJ, Gleadle JM, Ragoussis J, Ratcliffe PJ. 2009. Genome-wide association of hypoxia-inducible factor (HIF)- $1 \alpha$ and HIF- $2 \alpha$ DNA binding with expression profiling of hypoxia-inducible transcripts. I Biol Chem 284: 16767-16775.

Moore LG, Young D, McCullough RE, Droma T, Zamudio S. 2001a. Tibetan protection from intrauterine growth restriction (IUGR) and reproductive loss at high altitude. Am I Hum Biol 13: 635-644.

Moore LG, Zamudio S, Zhuang J, Sun S, Droma T. 2001b. Oxygen transport in Tibetan women during pregnancy at 3,658 m. Am J Phys Anthropol 114: 42-53.

Moore LG, Charles SM, Julian CG. 2011. Humans at high altitude: hypoxia and fetal growth. Respir Physiol Neurobiol 178: $181-190$.

Moslehi J, Minamishima YA, Shi J, Neuberg D, Charytan DM, Padera RF, Signoretti S, Liao R, Kaelin WG Jr. 2010. Loss of hypoxia-inducible factor prolyl hydroxylase activity in cardiomyocytes phenocopies ischemic cardiomyopathy. Circulation 122: 1004-1016.

Natarajan C, Inoguchi N, Weber RE, Fago A, Moriyama H, Storz JF. 2013. Epistasis among adaptive mutations in deer mouse hemoglobin. Science 340: 1324-1327.
Niermeyer S, Yang P, Shanmina, Drolkar, Zhuang J, Moore LG. 1995. Arterial oxygen saturation in Tibetan and Han infants born in Lhasa, Tibet. N Engl J Med 333: 1248-1252.

Niermeyer S, Zamdio S, Moore LG. 2001. The people. In High altitude: an exploration of human adaptation (ed. TF Hornbein, RB Schoene), pp. 42-100. Marcel Dekker, New York.

Papandreou I, Cairns RA, Fontana L, Lim AL, Denko NC. 2006. HIF-1 mediates adaptation to hypoxia by actively downregulating mitochondrial oxygen consumption. Cell Metab 3: $187-197$.

Penaloza D, Sime F, Banchero N, Gamboa R, Cruz J, Marticorena E. 1963. Pulmonary hypertension in healthy men born and living at high altitudes. Am I Cardiol 11: 150-157.

Peng YJ, Yuan G, Ramakrishnan D, Sharma SD, Bosch-Marce M, Kumar GK, Semenza GL, Prabhakar NR. 2006. Heterozygous HIF- $1 \alpha$ deficiency impairs carotid body-mediated systemic responses and reactive oxygen species generation in mice exposed to intermittent hypoxia. I Physiol 577: 705-716.

Peng Y, Yang Z, Zhang H, Cui C, Qi X, Luo X, Tao X, Wu T, Ouzhuluobu, Basang, et al. 2011a. Genetic variations in Tibetan populations and high-altitude adaptation at the Himalayas. Mol Biol Evol 28: 1075-1081.

Peng YJ, Nanduri J, Khan SA, Yuan G, Wang N, Kinsman B, Vaddi DR, Kumar GK, Garcia JA, Semenza GL, et al. 2011b. Hypoxia-inducible factor $2 \alpha$ (HIF- $2 \alpha$ ) heterozygous-null mice exhibit exaggerated carotid body sensitivity to hypoxia, breathing instability, and hypertension. Proc Natl Acad Sci 108: 3065-3070.

Percy MJ, Zhao Q, Flores A, Harrison C, Lappin TR, Maxwell $\mathrm{PH}, \mathrm{McMullin}$ MF, Lee FS. 2006. A family with erythrocytosis establishes a role for prolyl hydroxylase domain protein 2 in oxygen homeostasis. Proc Natl Acad Sci 103: 654-659.

Percy MJ, Furlow PW, Beer PA, Lappin TR, McMullin MF, Lee FS. 2007. A novel erythrocytosis-associated PHD2 mutation suggests the location of a HIF binding groove. Blood 110: 2193-2196.

Percy MJ, Beer PA, Campbell G, Dekker AW, Green AR, Oscier D, Rainey MG, van Wijk R, Wood M, Lappin TR, et al. 2008a. Novel exon 12 mutations in the HIF2A gene associated with erythrocytosis. Blood 111: 5400-5402.

Percy MJ, Furlow PW, Lucas GS, Li X, Lappin TR, McMullin MF, Lee FS. 2008b. A gain-of-function mutation in the HIF2A gene in familial erythrocytosis. N Engl J Med 358: 162-168.

Petousi N, Robbins PA. 2014. Human adaptation to the hypoxia of high altitude: the Tibetan paradigm from the pregenomic to the postgenomic era. J Appl Physiol 116: 875-884.

Petousi N, Croft QP, Cavalleri GL, Cheng HY, Formenti F, Ishida $\mathrm{K}$, Lunn $\mathrm{D}$, McCormack M, Shianna KV, Talbot NP, et al. 2014. Tibetans living at sea level have a hyporesponsive hypoxia-inducible factor system and blunted physiological responses to hypoxia. I Appl Physiol 116: 893-904.

Projecto-Garcia J, Natarajan C, Moriyama H, Weber RE, Fago A, Cheviron ZA, Dudley R, McGuire JA, Witt CC, Storz JF. 2013. Repeated elevational transitions in hemoglobin function during the evolution of Andean hummingbirds. Proc Natl Acad Sci 110: 20669-20674.

Qiu Q, Zhang G, Ma T, Qian W, Wang J, Ye Z, Cao C, Hu Q, Kim J, Larkin DM, et al. 2012. The yak genome and adaptation to life at high altitude. Nat Genet 44: 946-949.

Rankin EB, Wu C, Khatri R, Wilson TL, Andersen R, Araldi E, Rankin AL, Yuan J, Kuo CJ, Schipani E, et al. 2012. The HIF signaling pathway in osteoblasts directly modulates erythropoiesis through the production of EPO. Cell 149: 63-74.

Ratcliffe PJ. 2013. Oxygen sensing and hypoxia signalling pathways in animals: the implications of physiology for cancer. J Physiol 591: 2027-2042. 
Rytkonen KT, Williams TA, Renshaw GM, Primmer CR, Nikinmaa M. 2011. Molecular evolution of the metazoan PHD-HIF oxygen-sensing system. Mol Biol Evol 28: 19131926.

Scheinfeldt LB, Tishkoff SA. 2013. Recent human adaptation: genomic approaches, interpretation and insights. Nat Rev Genet 14: 692-702.

Scheinfeldt LB, Soi S, Thompson S, Ranciaro A, Woldemeskel D, Beggs W, Lambert C, Jarvis JP, Abate D, Belay G, et al. 2012. Genetic adaptation to high altitude in the Ethiopian highlands. Genome Biol 13: R1.

Schodel J, Oikonomopoulos S, Ragoussis J, Pugh CW, Ratcliffe PJ, Mole DR. 2011. High-resolution genome-wide mapping of HIF-binding sites by ChIP-seq. Blood 117: e207-e217.

Scortegagna M, Ding K, Zhang Q, Oktay Y, Bennett MJ, Bennett M, Shelton JM, Richardson JA, Moe O, Garcia JA. 2005. HIF-2 $\alpha$ regulates murine hematopoietic development in an erythropoietin-dependent manner. Blood 105: 3133-3140.

Semenza GL. 1999. Regulation of mammalian $\mathrm{O}_{2}$ homeostasis by hypoxia-inducible factor 1. Annu Rev Cell Dev Biol 15: 551-578.

Semenza GL. 2012. Hypoxia-inducible factors in physiology and medicine. Cell 148: 399-408.

Shao Z, Zhang Y, Powell-Coffman JA. 2009. Two distinct roles for EGL-9 in the regulation of HIF-1-mediated gene expression in Caenorhabditis elegans. Genetics 183: 821-829.

Shimoda LA, Laurie SS. 2014. HIF and pulmonary vascular responses to hypoxia. J Appl Physiol 116: 867-874.

Sime F, Banchero N, Penaloza D, Gamboa R, Cruz J, Marticorena E. 1963. Pulmonary hypertension in children born and living at high altitudes. Am J Cardiol 11: 143-149.

Simonson TS, Yang Y, Huff CD, Yun H, Qin G, Witherspoon DJ, Bai Z, Lorenzo FR, Xing J, Jorde LB, et al. 2010. Genetic evidence for high-altitude adaptation in Tibet. Science 329: 72-75.

Simonson TS, McClain DA, Jorde LB, Prchal JT. 2012. Genetic determinants of Tibetan high-altitude adaptation. Hum Genet 131: 527-533.

Skuli N, Majmundar AJ, Krock BL, Mesquita RC, Mathew LK, Quinn ZL, Runge A, Liu L, Kim MN, Liang J, et al. 2012. Endothelial HIF- $2 \alpha$ regulates murine pathological angiogenesis and revascularization processes. J Clin Invest 122: 1427-1443.

Song D, Li LS, Heaton-Johnson KJ, Arsenault PR, Master SR, Lee FS. 2013. Prolyl hydroxylase domain protein 2 (PHD2) binds a Pro-Xaa-Leu-Glu motif, linking it to the heat shock protein 90 pathway. I Biol Chem 288: 9662-9674.

Song D, Li LS, Arsenault PR, Tan Q, Bigham AW, HeatonJohnson KJ, Master SR, Lee FS. 2014. Defective Tibetan PHD2 binding to p23 links high altitude adaptation to altered oxygen sensing. I Biol Chem 289: 14656-14665.

Soria R, Julian CG, Vargas E, Moore LG, Giussani DA. 2013. Graduated effects of high-altitude hypoxia and highland ancestry on birth size. Pediatr Res 74: 633-638.

Staub NC. 1980. Pulmonary edema-hypoxia and overperfusion. $N$ Engl I Med 302: 1085-1087.

Storz JF, Scott GR, Cheviron ZA. 2010. Phenotypic plasticity and genetic adaptation to high-altitude hypoxia in vertebrates. J Exp Biol 213: 4125-4136.

Storz JF, Opazo JC, Hoffmann FG. 2013. Gene duplication, genome duplication, and the functional diversification of vertebrate globins. Mol Phylogenet Evol 66: 469-478.

Sturm RA. 2009. Molecular genetics of human pigmentation diversity. Hum Mol Genet 18: R9-R17.

Sui GJ, Liu YH, Cheng XS, Anand IS, Harris E, Harris P, Heath D. 1988. Subacute infantile mountain sickness. J Pathol 155: 161-170.
Takeda K, Ho VC, Takeda H, Duan LJ, Nagy A, Fong GH. 2006. Placental but not heart defects are associated with elevated hypoxia-inducible factor $\alpha$ levels in mice lacking prolyl hydroxylase domain protein 2. Mol Cell Biol 26: 8336-8346.

Takeda K, Cowan A, Fong GH. 2007. Essential role for prolyl hydroxylase domain protein 2 in oxygen homeostasis of the adult vascular system. Circulation 116: 774-781.

Takeda K, Aguila HL, Parikh NS, Li X, Lamothe K, Duan LJ, Takeda H, Lee FS, Fong GH. 2008. Regulation of adult erythropoiesis by prolyl hydroxylase domain proteins. Blood 111: 3229-3235.

Takeda N, O'Dea EL, Doedens A, Kim JW, Weidemann A, Stockmann C, Asagiri M, Simon MC, Hoffmann A, Johnson RS. 2010. Differential activation and antagonistic function of HIF- $\alpha$ isoforms in macrophages are essential for NO homeostasis. Genes Dev 24: 491-501.

Takubo K, Goda N, Yamada W, Iriuchishima H, Ikeda E, Kubota Y, Shima H, Johnson RS, Hirao A, Suematsu M, et al. 2010. Regulation of the HIF-1 $\alpha$ level is essential for hematopoietic stem cells. Cell Stem Cell 7: 391-402.

Tan Q, Kerestes H, Percy MJ, Pietrofesa R, Chen L, Khurana TS, Christofidou-Solomidou M, Lappin TR, Lee FS. 2013. Erythrocytosis and pulmonary hypertension in a mouse model of human HIF2A gain of function mutation. J Biol Chem 288: 17134-17144.

Taniguchi CM, Finger EC, Krieg AJ, Wu C, Diep AN, LaGory EL, Wei K, McGinnis LM, Yuan J, Kuo CJ, et al. 2013. Cross-talk between hypoxia and insulin signaling through $\mathrm{Phd} 3$ regulates hepatic glucose and lipid metabolism and ameliorates diabetes. Nat Med 19: 1325-1330.

Taylor MS. 2001. Characterization and comparative analysis of the EGLN gene family. Gene 275: 125-132.

Udpa N, Ronen R, Zhou D, Liang J, Stobdan T, Appenzeller O, Yin Y, Du Y, Guo L, Cao R, et al. 2014. Whole genome sequencing of Ethiopian highlanders reveals conserved hypoxia tolerance genes. Genome Biol 15: R36.

Wang B, Zhang YB, Zhang F, Lin H, Wang X, Wan N, Ye Z, Weng H, Zhang L, Li X, et al. 2011. On the origin of Tibetans and their genetic basis in adapting high-altitude environments. PLOS ONE 6: e17002.

Weil JV, Byrne-Quinn E, Sodal IE, Filley GF, Grover RF. 1971. Acquired attenuation of chemoreceptor function in chronically hypoxic man at high altitude. J Clin Invest 50: 186-195.

Weitz CA, Garruto RM. 2007. A comparative analysis of arterial oxygen saturation among Tibetans and Han born and raised at high altitude. High Alt Med Biol 8: 13-26.

Wenger RH, Stiehl DP, Camenisch G. 2005. Integration of oxygen signaling at the consensus HRE. Sci STKE 2005: re12.

Winslow RM, Chapman KW, Gibson CC, Samaja M, Monge CC, Goldwasser E, Sherpa M, Blume FD, Santolaya R. 1989. Different hematologic responses to hypoxia in Sherpas and Quechua Indians. J Appl Physiol 66: 1561-1569.

Wu T, Kayser B. 2006. High altitude adaptation in Tibetans. High Alt Med Biol 7: 193-208.

Xia X, Lemieux ME, Li W, Carroll JS, Brown M, Liu XS, Kung AL. 2009. Integrative analysis of HIF binding and transactivation reveals its role in maintaining histone methylation homeostasis. Proc Natl Acad Sci 106: 4260-4265.

Xiang K, Ouzhuluobu, Peng Y, Yang Z, Zhang X, Cui C, Zhang H, Li M, Zhang Y, Bianba et al. 2013. Identification of a Tibetanspecific mutation in the hypoxic gene EGLN1 and its contribution to high-altitude adaptation. Mol Biol Evol 30: 1889-1898.

Xing J, Wuren T, Simonson TS, Watkins WS, Witherspoon DJ, Wu W, Qin G, Huff CD, Jorde LB, Ge RL. 2013. Genomic analysis of natural selection and phenotypic variation in high-altitude mongolians. PLoS Genet 9: e1003634. 
Xu S, Li S, Yang Y, Tan J, Lou H, Jin W, Yang L, Pan X, Wang J, Shen $Y$, et al. 2011. A genome-wide search for signals of highaltitude adaptation in Tibetans. Mol Biol Evol 28: 1003-1011.

Yi X, Liang Y, Huerta-Sanchez E, Jin X, Cuo ZX, Pool JE, Xu X, Jiang H, Vinckenbosch N, Korneliussen TS, et al. 2010. Sequencing of 50 human exomes reveals adaptation to high altitude. Science 329: 75-78.

Yu AY, Shimoda LA, Iyer NV, Huso DL, Sun X, McWilliams R, Beaty T, Sham JS, Wiener CM, Sylvester JT, et al. 1999. Impaired physiological responses to chronic hypoxia in mice partially deficient for hypoxia-inducible factor $1 \alpha$. J Clin Invest 103: 691-696.

Yu F, White SB, Zhao Q, Lee FS. 2001. HIF-1 $\alpha$ binding to VHL is regulated by stimulus-sensitive proline hydroxylation. Proc Natl Acad Sci 98: 9630-9635.

Yuan G, Peng YJ, Reddy VD, Makarenko VV, Nanduri J, Khan SA, Garcia JA, Kumar GK, Semenza GL, Prabhakar NR. 2013. Mutual antagonism between hypoxia-inducible factors $1 \alpha$ and $2 \alpha$ regulates oxygen sensing and cardio-respiratory homeostasis. Proc Natl Acad Sci 110: E1788-E1796.

Zamudio S, Droma T, Norkyel KY, Acharya G, Zamudio JA, Niermeyer SN, Moore LG. 1993. Protection from intrauterine growth retardation in Tibetans at high altitude. Am I Phys Anthropol 91: 215-224.

Zhang H, Gao P, Fukuda R, Kumar G, Krishnamachary B, Zeller KI, Dang CV, Semenza GL. 2007. HIF-1 inhibits mitochondrial biogenesis and cellular respiration in VHL-deficient renal cell carcinoma by repression of C-MYC activity. Cancer Cell 11: 407-420.

Zhang P, Yao Q, Lu L, Li Y, Chen PJ, Duan C. 2014. Hypoxiainducible factor 3 is an oxygen-dependent transcription activator and regulates a distinct transcriptional response to hypoxia. Cell Reports 6: 1110-1121.

Zhou D, Haddad GG. 2013. Genetic analysis of hypoxia tolerance and susceptibility in Drosophila and humans. Annu Rev Genomics Hum Genet 14: 25-43.

Zhou D, Xue J, Lai JC, Schork NJ, White KP, Haddad GG. 2008. Mechanisms underlying hypoxia tolerance in Drosophila melanogaster: hairy as a metabolic switch. PLoS Genet 4: e1000221.

Zhou D, Udpa N, Gersten M, Visk DW, Bashir A, Xue J, Frazer KA, Posakony JW, Subramaniam S, Bafna V, et al. 2011. Experimental selection of hypoxia-tolerant Drosophila melanogaster. Proc Natl Acad Sci 108: 2349-2354.

Zhou D, Udpa N, Ronen R, Stobdan T, Liang J, Appenzeller O, Zhao HW, Yin Y, Du Y, Guo L, et al. 2013. Whole-genome sequencing uncovers the genetic basis of chronic mountain sickness in Andean highlanders. Am J Hum Genet 93: 452-462.

Zhuang J, Droma T, Sun S, Janes C, McCullough RE, McCullough RG, Cymerman A, Huang SY, Reeves JT, Moore LG. 1993. Hypoxic ventilatory responsiveness in Tibetan compared with Han residents of 3,658 m. J Appl Physiol 74: 303-311. 


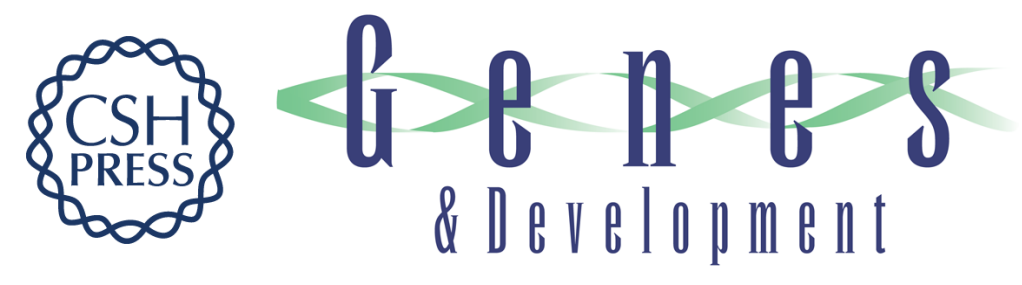

\section{Human high-altitude adaptation: forward genetics meets the HIF pathway}

Abigail W. Bigham and Frank S. Lee

Genes Dev. 2014, 28:

Access the most recent version at doi:10.1101/gad.250167.114

$\begin{aligned} & \text { References } \begin{array}{l}\text { This article cites } 183 \text { articles, 68 of which can be accessed free at: } \\ \text { http://genesdev.cshlp.org/content/28/20/2189.full.html\#ref-list-1 }\end{array} \\ & \begin{aligned} \text { Creative } \\ \text { Commons } \\ \text { License }\end{aligned} \begin{array}{l}\text { This article is distributed exclusively by Cold Spring Harbor Laboratory Press for the first } \\ \text { six months after the full-issue publication date (see } \\ \text { http://genesdev.cshlp.org/site/misc/terms.xhtml). After six months, it is available under a } \\ \text { Creative Commons License (Attribution-NonCommercial } 4.0 \text { International), as described } \\ \text { at http://creativecommons.org/licenses/by-nc/4.0/. }\end{array} \\ & \begin{array}{l}\text { Receive free email alerts when new articles cite this article - sign up in the box at the top } \\ \text { right corner of the article or click here. }\end{array} \\ & \text { Service }\end{aligned}$

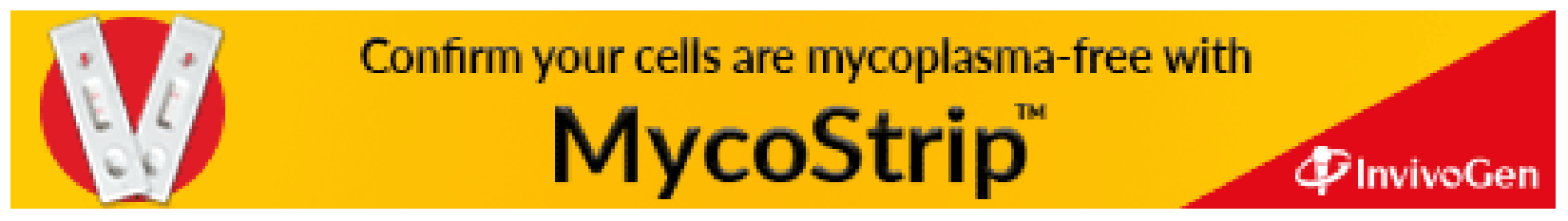

